\title{
La política mediterránea de Primo de Rivera: el triángulo Hispano-Italo-Francés
}

\author{
Susana Sueiro SeoAne
}

Las relaciones hispano-italianas durante la Dictadura de Primo de Rivera han sido estudiadas por la autora del presente artículo en lo que constituyó su Memoria de Licenciatura (UAM, 1983). Utilizó para ello las fuentes diplomáticas y bibliográficas tanto españolas como italianas y una muy apretada síntesis de este trabajo se publicó en el $n .^{\circ} 1$ de Proserpina (Revista de la UNED, Mérida). El artículo presentado ahora supone un enfoque del mismo tema desde la óptica francesa, a la luz de la documentación de los archivos diplomáticos del Ministerio de Asuntos Exteriores francés.

En 1923 no era nueva la idea de un entendimiento italo-español. Desde hacía bastantes años venían apareciendo periódicamente en la prensa de los dos paises noticias en este sentido. Durante la Primera Guerra mundial había habido manifestaciones de esta tendencia, conversaciones de Dato y Romanones con Sonnino, siempre propiciadas por el embajador español en Roma, marqués de Villaurrutia - deseoso de obtener un éxito diplomático - que fueron seguidas con interés y cierta inquietud por Francia, puesto que desde el primer momento estuvo claro que el objetivo principal de un posible acercamiento hispano-italiano era hacer contrapeso a la política francesa en el Mediterráneo. También parecía estar claro para los franceses que la iniciativa provenía de Italia. La neutralidad española en la guerra imposibilitó sin embargo cualquier resultado positivo y práctico de este intento de aproximación. En los años siguientes a la contienda continuaron existiendo cierto número de circunstancias que no jugaban a favor de una alianza política - y menos aún militar - entre las dos penínsulas mediterráneas. Existian sentimientos de antipatía hacia Italia en un amplio sector público español en el que estaba comprendida la familia real que, por influencia de la Reina Madre, "austriaca hasta el fondo 
de su corazón", veía en la Casa de Saboya no sólo a la "usurpadora" del poder temporal del Papa sino también a quien, traicionando a sus aliados de otro tiempo, había contribuido al derrumbamiento de Austria y a la ruina de los Habsburgo. Había que tener en cuenta, además, la impotencia militar y naval de España y su deseo de no renunciar a la neutralidad. Según el embajador francés, tanto el Gobierno como la opinión pública estaban resueltos a conservarla, porque todavía pesaba mucho sobre ellos el recuerdo de Cuba y también porque había reportado grandes ganancias para comerciantes, banqueros y productores españoles que comparaban con orgullo sus beneficios con los de la victoria para los aliados. Por otra parte, no parecia posible un acuerdo mediterráneo entre las dos penínsulas al margen de Inglaterra, potencia mediterránea de primer orden que tanto Roma como Madrid estaban obligadas a tener en cuenta, y este país no haría nada que perjudicase a su aliada francesa, o que pudiera alterar el statu quo en dicho mar. Por último, desde el punto de vista comercial, existían dificultades entre Italia y España derivadas de una producción análoga, y no parecía que la tendencia fuera multiplicar los intercambios, ya escasos antes y durante la guerra.

A finales de 1921, de todas formas, el embajador francés en Madrid, Defrance, debe reconocer que, cada vez más, una importante parte de la prensa española se manifiesta claramente hostil a Francia y defiende la necesidad de una política de entendimiento con Italia. El órgano principal de esta campaña es La Correspondencia Militar pero se generaliza en toda la prensa conservadora germanófila y en los círculos políticos que la inspiran y que, "inconsolables por no poder apostar de aquí en adelante a la carta alemana, se ilusionan ahora con la esperanza de crearnos graves dificultades, o por lo menos, graves motivos de inquietud en la región mediterránea" ', según asegura Defrance. Pero de momento estas manifestaciones no hallan eco en el Gobierno ${ }^{2}$.

En octubre de 1922, Mussolini accede al poder en Italia y en diciembre se constituye en Madrid el que será el último Gobierno constitucional anterior al golpe de estado de Primo de Rivera, el gabinete liberal de García Prieto. Es en este momento cuando el Gobierno español se interesa realmente por una política de acercamiento a Italia y sin duda es la cuestión de Tánger - que, junto con Marruecos, era el principal punto de fricción con Francia - la que determina esta orientación.

\footnotetext{
'Defrance a Poincaré. Madrid, 6 de julio de 1922. N. 399: "España e Italia". Serie 1918-29 (Europe), Espagne, N. ${ }^{\circ}$ 60: Rélations avec l'italie. ADMAE (París).

2 lbid.
} 
La Conferencia tripartita (en ella intervenían Gran Bretaña, Francia y España, pero no Italia, a pesar de sus esfuerzos por ser admitida) que debía establecer el régimen al que se sometería la administración de Tánger transcurría con poco éxito, sufriendo frecuentes interrupciones, y las demandas españolas encontraban siempre la oposición de Francia. El Ministro de Estado, Santiago Alba, confió al embajador italiano enjunio de 1923 su creencia en "la firme y sólida amistad que debe unir a nuestros dos países contra el enemigo común, para la defensa del Mediterráneo" ${ }^{3}$ y, en septiembre, fue el Conde de Romanones quien expresó la idea de "la necesidad de establecer vínculos más estrechos entre España e Italia para obligar a Francia a modificar su postura y hacer que comprenda que los otros dos países mediterráneos no se proponen dejar en sus manos las llaves del mar común" ". El embajador italiano, Paulicci de' Calboli, habia ocupado su puesto en enero de ese año y, por su parte, el Gobierno español había mandado a Roma en marzo a Francisco de Reynoso, a quien Santiago Alba enviaba en uno de sus primeros telegramas las instrucciones siguientes:

\footnotetext{
"Conviene que sepa V.E. que el gobierno de S.M. coincide con predisposición espíritu Gobierno italiano favorable a inteligencia sobre política mediterránea y así lealmente lo pusimos en labios de S.M. el Rey al contestar éste al discurso presentación credenciales nuevo Embajador en Madrid" 5 .
}

Alba tratará de agilizar las negociaciones para el viaje de Alfonso XIII a Roma y para la conclusión del tratado comercial hispano-italiano, condiciones imprescindibles para el estrechamiento de los lazos políticos. Estas son las circunstancias cuando se produce el golpe de Primo de Rivera. Cuando sólo se han cumplido tres meses desde el advenimiento de la Dictadura, los reyes y el dictador español emprenden un apoteósico viaje a Italia.

\footnotetext{
${ }^{3}$ Paulucci de Calboli a Mussolini. Madrid, 12 de junio de 1923. DDI, 7.. serie, vol, II, n. 74. Véase también: Corbin, encargado de negocios, a Poincaré. San Sebastián, 6 de septiembre de 1923. N. ${ }^{\circ}$ 504: "España e Italia", y N.o 216, de 31 de agosto de 1923. ADMAE (París), N. 60.

${ }^{4}$ Paulicci de Calboli a Mussolini. Madrid, 7 de septiembre de 1923. Tel. N. ${ }^{\circ} 196$. MAE (Roma), Política, b. 1588.

${ }^{5}$ Santiago Alba a Reynoso. Madrid, 24 de marzo de 1923. Tel. N. ${ }^{\circ}$ 269/49. AMAE (Madrid), Serie Correspondencia, N. ${ }^{\circ} 1627$.
} 


\section{EL VIAJE DE ALFONSO XIII Y PRIMO DE RIVERA A ITALIA}

El viaje a Italia de los soberanos españoles, acompañados por el dictador, era vivamente deseado tanto en España como en Italia. Prueba del interés que despierta en ambos Gobiernos es el apresuramiento con que se firma el tratado comercial, justamente el día de la salida delos reyes hacia Roma, que llevaba discutiéndose muchísimo tiempo sin que hubiera podido alcanzarse ningún acuerdo ${ }^{6}$. El golpe de Estado de Primo de Rivera coincide con un momento en el que, a causa del grave empeoramiento de las relaciones italo-francesas que enseguida se transformará en decidida oposición entre ambos países, Mussolini cree muy interesante establecer una alianza con España y el viaje constituye el primer y necesario paso dentro del proceso de acercamiento. Además, el Duce quiere que Alfonso XIII le sirva como intermediario en su política de aproximación al Vaticano. Desde el punto de vista de Primo de Rivera, el contacto con Mussolini proporciona prestigio a su recién nacido régimen, tanto en el exterior como en el interior; al dictador español le interesa dar la imagen de un país comprometido en un camino paralelo al italiano que debe conducir inevitablemente a su regeneración y grandeza. Por otro lado, se le brinda la oportunidad de intimidar un poco a Francia, demostrándole que cuenta con buenos amigos con quienes hacer frente a sus "injerencias". También Alfonso XIII desea realizar la visita, no sólo por "saborear el fruto prohibido hasta ahora", según palabras del embajador italiano Paulicci ${ }^{7}$ sino porque el rey, "del que son conocidos sus sentimientos poco francófilos" ${ }^{8}$, es claramente partidario de una alianza hispano-italiana que detenga los "planes anti-españoles" de Francia ${ }^{~}$. La Reina Madre es la única que sigue odiando a Italia ${ }^{10}$.

\footnotetext{
${ }^{6}$ Véase: Barrere a Poincaré. Roma, 29 de noviembre de 1923. N. ${ }^{\circ}$ 570. ADMAE (París), N. ${ }^{\circ} 60$.

${ }^{7}$ Paulucci a Mussolini. Madrid, 25 de febrero de 1923. MAE (Roma), Política, b. 1588. Desde la formación del Estado italiano en 1870 , que se habia incorporado las posesiones pontificias, los reyes españoles no realizaban visitas oficiales a este país. España, como nación católica, apoyaba al Papa negándose a reconocer al Estado "usurpador". Tras la llegada de Mussolini al poder, había habido un intento de acercamiento entre el Quirinal y la Santa Sede por lo que la llamada "cuestión romana" ya no era un impedimento tan grave para la visita de los monarcas católicos.

${ }^{8}$ Paulucci a Mussolini. Madrid, 13 de febrero de 1923. Tel. N. ${ }^{\circ}$ 361/102. MAE (Roma), Política, b. 1588 .

${ }^{9}$ Véase: Tel. N. ${ }^{\circ}$ 342/95, Paulucci a Mussolini, Madrid, 11 de febrero de 1923; Tel. N. ${ }^{\circ}$ 318/128 gab 44, Paulucci a Mussolini, Madrid, 14 de junio de 1923; Tel. N. ${ }^{\circ}$ 111/57/gab 25, Paulucci a Mussolini, Madrid, 11 de marzo de 1923, en MAE (Roma), Política, b. 1588.

${ }^{10}$ Véase: Paulucci a Mussolini, Madrid, 25 de febrero de 1923. MAE (Roma), Política, b. 1588.
} 
¿Qué resultados concretos pueden derivarse de esta, al parecer, coincidencia de intereses entre los Gobiernos italiano y español? El embajador francés en Roma, Barrere, comenta que no se ha descuidado nada para dar a la visita real el mayor brilio posible y que sus resonancias son incomparablemente mayores que las de los recientes viajes a Roma de los soberanos belgas e ingleses, pero se inclina a creer que las manifestaciones oficiales hispano-italianas tienden sobre todo a demostrar la solidez de los dos regímenes más que a preparar el renacimiento de una amistad activa entre ambos países ${ }^{11}$. Barrere opina que "los primeros ministros italiano y español, por razones de orden interno, tienen interés en infundir en la opinión pública de los países que dirigen la impresión de que hacen una política exterior de gran envergadura y fecunda en resultados"12, pero piensa que estas calurosas manifestaciones son lógicas y que, aunque conviene seguirlas de cerca, es imprudente que la prensa francesa exagere la importancia del viaje; por el contrario, debe restársela, reduciéndolo a las proporciones de un acto de cortesía del rey de España hacia el Papa y hacia el monarca italiano. En la Embajada francesa en Madrid se produce por estas fechas un cambio de embajador al que no es ajeno el interés del Gobierno de la República por estar alerta de todos los movimientos de aproximación entre España e Italia. Mientras no llega a Madrid el nuevo embajador, Fontanay, es el encargado de negocios, Corbin, quien asume sus funciones. Corbin parece ser de la misma opinión que Barrere cuando afirma que España se siente poco dispuesta a las aventuras, que le basta con su reorganización interna y los problemas de Marruecos, y que "lo que atrae sobre todo hacia Italia a su Gobierno actual es el ejemplo de una Dictadura que ha tenido éxito. El deseo que este país podría tener de ocupar un puesto más importante en las cuestiones mediterráneas se subordinará siempre a la preocupación por proteger su neutralidad" 13 .

Sin embargo, a nadie escapa, y menos a los franceses, que en el acercamiento hispano-italiano que se está produciendo hay un matiz antifrancés evidente. Es indudable que en España existe un malestar por la actitud francesa ante ciertos temas que, como Tánger, interesan a ésta. Como ya hemos señalado, ese malestar no es nuevo. Algunos periódicos como La Correspondencia Militar, El Imparcial, ABC o Informaciones venían manifestando con frecuencia sentimientos claramente francófobos; en determinados círculos políticos y militares se propugnaba desde hacía tiempo un entendimiento con Italia como medio de frenar los deseos "hegemónicos" de Francia; y una parte importante de la opinión pública veía

\footnotetext{
${ }^{11}$ Barrere a Poincaré. Roma, 22 de noviembre de 1923. ADMAE (París), N. 60.

${ }^{12}$ Barrere a Poincaré. Roma, 15 de noviembre de 1923. ADMAE (París), N. ${ }^{\circ} 60$.

${ }^{13}$ Corbin a Poincaré. Madrid, 24 de noviembre de 1923, N. ${ }^{\circ} 648$. ADMAE (París), N. 60.
} 
con satisfacción la tendencia al acercamiento hispano-italiano, fundamentalmente por el hecho de que pudiera existir éste sin contar para nada con Francia y sin que la República vecina pudiera hacer nada para evitarlo. Según Corbin, "España, que parece a ratos inconsolable por haberse quedado en una potencia de segundo orden, nos hace responsables del olvido en que se encuentra. Ahora nos lanza una mirada triunfal porque se cree a punto de representar un papel en la política mundial" ${ }^{14}$. Unos días antes de la salida de los reyes para Roma, $A B C$, dedicándose a despejar el significado de este viaje "histórico", presenta como base del acercamiento hispano-italiano la necesidad que tienen España e Italia de garantizar el equilibrio en el Mediterráneo occidental, "tras la eliminación previa de toda tentativa de una tercera potencia a ejercer allí su hegemonía y convertir Tánger en una base naval" ${ }^{15}$. No había, desde luego, necesidad de precisar a quién se entendía que designaba la expresión de "tercera potencia".

En Italia, por su parte, está igualmente claro que la opinión pública y la prensa atribuyen al viaje y a la aproximación entre ambos países un carácter en gran medida anti-francés, y ambas se congratulan de ello. Un diplomático francés escribe a su Gobierno desde Roma que el pueblo italiano, atizado por la decepción que experimenta al ver a Italia definitivamente excluida de la Conferencia de Tánger, aprovecha la ocasión de la visita del rey de España para "una especie de revancha" y que cierto número de órganos italianos hace "comentarios lacerantes" contra Francia ${ }^{16}$ que con su prepotencia, ingratitud y egoísmo ha ofendido el orgullo de Italia y España como potencias mediterráneas, excluyendo a la primera y relegando a la segunda a una posición insignificante en la cuestión tangerina. En esta tónica, el Roma de Nápoles escribe: "Francia y Gran Bretaña querrían considerar a Italia como una entidad despreciable en este mar que la baña; y por eso, la perspectiva de una estrecha unión entre las dos penínsulas meridionales no les complace, porque esta unión garantizaría a Italia y a España el lugar que les corresponde y una influencia legítima en las cuestiones mediterráneas que hasta ahora han estado monopolizadas por los gabinetes de París y Londres. Pero éstos tendrán que hacerse en adelante a la idea de que Italia ya no está aislada" ${ }^{17}$.

En Francia se extienden rumores alarmistas sobre la conclusión de un acuerdo militar y naval italo-español cuya finalidad primordial es aislar a la República cortando sus comunicaciones con el norte de Africa. Son habi-

\footnotetext{
${ }^{14}$ Corbin a Poincaré. Madrid, 24 de noviembre de 1923, N. ${ }^{\circ} 648$. ADMAE (París), N. ${ }^{\circ} 60$.

${ }^{15}$ Corbin a Poincaré. Madrid, 16 de noviembre de 1923, N. ${ }^{\circ} 309$. ADMAE (París), N. 60.

${ }^{16}$ Charles Roux a Poincaré. Roma, 4 de diciembre de 1923, N. ${ }^{\circ} 576$. ADMAE (París), N. ${ }^{\circ} 60$.

17 Roma, Nápoles, 29 de noviembre de 1923.
} 
tuales artículos como el del diputado-alcalde de Constantina (Argelia), Emile Morinaud, que termina diciendo, en tono apocalíptico: "Jamás fue la hora tan grave para nosotros: Francia no puede vivir sin sus Africas. Sus Africas quieren seguir siendo francesas. ¡Actuemos!” En este artículo, titulado "El peligro italo-español" y publicado en Tribune Libre, su autor propone un minucioso plan de construcción de submarinos, bombarderos, etc, para reforzar la aviación y la marina de guerra de Francia, con un gasto de 2.500 millones de francos. Otros periódicos reclaman también el voto urgente de un programa de construcción naval al hacer cálculos como Le Matin - sobre las fuerzas navales de las tres potencias y llegar a la alarmante conclusión de que la marina italiana es superior a la francesa en varios aspectos y que si, además, llega a contar con el apoyo de la española, su superioridad será entonces absoluta ya que, aunque la fuerza naval de España es relativamente débil, este país cuenta con la ventaja de poseer la base de las Baleares.

El Gobierno francés, y concretamente Poincaré, a la vista de los informes recibidos de sus embajadas en Madrid y Roma, considera exagerados estos temores y excluye la posibilidad de que haya podido firmarse un acuerdo secreto entre España e Italia con motivo de la visita real. Aun así, en las instrucciones que envía a Fontenay para su actuación en Madrid (éste presenta sus cartas credenciales el 12 de febrero de 1924), le dice a propósito de Italia: "No necesito insistir sobre la importancia que tiene para nosotros cualquier modificación del equilibrio mediterráneo. Le ruego me informe muy exactamente sobre esta cuestión que afecta a nuestros intereses vitales, singularmente en tiempo de guerra"18. Pero la cuestión de las relaciones italo-españolas y de los posibles resultados del viaje a Roma es sólo un punto de los muchos tratados en estas instrucciones y que no figura siquiera en los primeros lugares, reservados para asuntos al parecer de mayor importancia para el Gobierno francés, como Marruecos, Tánger o las relaciones comerciales. Poincaré se muestra, por tanto, relativamente tranquilo porque, a pesar del espíritu francófobo imperante en amplios sectores españoles e italianos, a pesar de "ciertas aristas ocultas" que parecen adivinarse en el resonante acercamiento entre los dos Gobiernos dictatoriales, a pesar de la particular animadversión de Mussolini hacia Francia y de las veleidades de actuación internacional de la Dictadura española, que sueña con que España ocupe un puesto de potencia de primer orden, lo cierto es que, del pormenorizado seguimiento de la visita a Roma, extrae la conclusión de que Primo de Rivera ha optado por evitar herir las susceptibilidades francesas y por calmar los ánimos que la visita

\footnotetext{
${ }^{18}$ Proyecto de Carta para M. Fontenay, embajador de la República francesa en Madrid: "Instrucciones". París, 25 de febrero de 1924. ADMAE (París), N. ${ }^{\circ} 60$.
} 
está suscitando en Francia. De las declaraciones del dictador y del rey en Italia, y de los comentarios de la prensa española se desprende, en efecto, que existe una consigna de eludir el espinoso tema de la colaboración hispano-italiana en el Mediterráneo, con sus implicaciones de "jaque a la política francesa" y de hacer, sin embargo, hincapié en otros temas "más apacibles". Las primeras manifestaciones oficiales corresponden a las efectuadas por el soberano en Valencia - ciudad en la que embarcan con rumbo a Italia - en un banquete ofrecido por el Ayuntamiento, en las que no hay ninguna alusión al papel que España e Italia pueden desempeñar en el Mediterráneo ni a su relación con Francia. Alfonso XIIl centra la razón de su visita en el deseo de "postrarse a los pies del Pontífice Romano" y en la misión común que corresponde a españoles e italianos en América del Sur. A partir de este momento, ambos temas - aumento de la fuerza espiritual de España por su más estrecho acercamiento a la Santa Sede, y supresión de la rivalidad hispano-italiana en las repúblicas del otro lado del Océano - serán el leit-motiv de las declaraciones a la prensa por parte española y en ellos se inspiran los brindis del rey y Primo de Rivera. La colaboración en Suramérica no había sido un aspecto tratado por España e Italia sino de una forma accesoria y resulta evidente que el continuo recurso a este tema poco problemático es una forma de dar fuerza a la prosa oficial sin necesidad de referirse a aspectos que se saben inquietantes para Francia y Gran Bretaña. En cuanto a la "devoción filial al Pontífice", Corbin escribe a Poincaré: "En los medios oficiales parece que se dedican ahora a limitar el alcance político del viaje de los Soberanos a Italia, insistiendo sólo en los efectos que cabe esperar de la visita al Vaticano desde el punto de vista de la política interior de España" 19. A lo largo del viaje y en las semanas siguientes al mismo seguirá acentuándose este carácter confesado de la visita.

\section{PARECE QUE PRIMO DE RIVERA QUIERE ESTAR A BIEN CON FRANCIA}

Así pues, el gran programa de acción mediterránea contra las tentativas de hegemonía de una "tercera potencia", que gran parte de la prensa, la opinión y los gobernantes propiciaban, cede paso a los temas vagos e inofensivos ya aludidos y los periódicos, en evidente contraste con lo que venía ocurriendo hasta entonces y siguiendo las directrices del Gobierno,

\footnotetext{
${ }^{19}$ Corbin a Poincaré. Madrid, Tel. N. ${ }^{\circ} 320$, s.f., recibido el 8 de diciembre de 1923. ADMAE (Paris), N. ${ }^{\circ}$ 60. Véase también: Corbin a Poincaré. Madrid, 2 de febrero de 1924, N. ${ }^{\circ} 62:$ "Acercamiento italo-españo'". ADMAE (Paris), N. ${ }^{\circ} 60$.
} 
se refieren pocas veces a Francia y si lo hacen es para afirmar la necesidad de incluir a la República vecina en ese "bloque latino" del que tanto se habla y que, por lo demás, no podrá hacer abstracción - según se dice - de la fraternidad portuguesa ni de la amistad británica. Pero esto por sí solo no bastaría para tranquilizar al Gobierno francés sobre la falta de resultados concretos de la visita, no obstante la intimidad y extremada cordialidad con que se ha desarrollado. Estaban también 'las seguridades dadas a Francia por altas personalidades políticas españolas incluido el propio dictador. El embajador francés, en su primera entrevista con el presidente del directorio tras el viaje obtenía plenas garantías sobre la intención del Gobierno español: "El General Primo de Rivera, en cuanto entré en su gabinete, me dijo: 'Querido Embajador, quiero que mis primeras palabras sean para darle la seguridad de que, a pesar de lo que hayan podido publicar ciertos periódicos, nada se ha hecho ni se ha dicho durante la visita del rey a Italia de lo que Francia pueda tener el menor recelo. España y Francia son amigas. Espero que lo sigan siendo siempre y España no ha hecho ni hará nada contrario a esta amistad. En cuanto a mi, personalmente, no es de hoy de cuando viene mi sincera amistad por su país, y le aseguro que no estoy en modo alguno dispuesto a cambiar de sentimientos. Sé muy bien que ha habido en un momento dado un punto negro entre Vds. y nosotros: se trata de Tánger. Pero este punto negro no es susceptible de modificar el conjunto de nuestras relaciones y yo deseo, por lo demás muy vivamente, que esta cuestión se resuelva pronto ${ }^{20}$ '".

Por esas mismas fechas, el embajador de España en París, Quiñones de León, explicaba a Peretti, entonces director de Asuntos Políticos en el Ministerio de Asuntos Exteriores francés, que "contrariamente a lo que se había publicado y a lo que se había creído en ciertos medios, nada se había concertado entre Mussolini y el general Primo de Rivera durante el viaje a Italia, que sólo ha sido un viaje de cortesía en el que únicamente se ha hablado de política de una manera general. Era, por otra parte, un viaje previsto desde hacía muchos años y no tenía otro fin que el de estrechar los lazos de una amistad natural" ${ }^{21}$. En el cambio de actitud del Gobierno español, Quiñones de León se atribuye un papel decisivo y comenta en el Quai d'Orsay que fue él quien había sugerido a Primo de Rivera que diese toda clase de garantías al embajador francés en lo concerniente a las relaciones políticas de España e Italia. El embajador italiano en Madrid, Paulicci, que percibe claramente el "enfriamiento" del dictador español con

\footnotetext{
60.

${ }^{20}$ Defrance a Poincaré. Madrid, 15 de diciembre de 1923. Tel. N. ${ }^{\circ} 344$ Bis. ADMAE (Paris), N. ${ }^{\circ}$

21 "Conversación del señor Quiñones de León con el señor Peretti", 14 de diciembre de 1923. ADMAE (París), N. ${ }^{\circ} 60$.
} 
respecto al proyecto de alianza hispano-italiana, cree efectivamente que Primo ha estado sometido a presiones tanto de la embajada francesa en Madrid como de la española en París. "Lo cierto - dice- es que mehe encontrado delante de un presidente que no tenía ya para Francia el lenguaje rígido y severo de hace algunas semanas" ${ }^{22}$. Los diplomáticos franceses opinan muy atinadamente, creo yo - que ha sido en última instancia la propia prudencia de Primo de Rivera la que ha dictado su forma de actuar: a la hora de la verdad, viendo llegado el momento de concretar en una actuación precisa lo que hasta ahora no han sido más que manifestaciones verbales, prefiere no arriesgarse en aventuras inciertas y quizá peligrosas o, en palabras de Corbin, "en cuanto se ha tratado de pasar al terreno de los hechos, ha sentido debilitarse su ardor emprendedor y ha soltado lastre" ${ }^{23}$.

\section{NO CESAN LOS RUMORES DE ENTENTE ITALO-ESPAÑOLA}

Sin embargo, Francia se ve obligada a no perder detalle del desarrollo de la pretendida amistad italo-española ante la persistencia de síntomas preocupantes, como la existencia de textos de supuestos convenios militares y navales secretos entre España e Italia, o la fría y distante actitud manifestada por Alfonso XIII tras la solución dada al problema de Tánger (el Estatuto de 1923 suponía la victoria de las tesis francesas).

Las informaciones sobre presuntos acuerdos militares y navales italoespañoles que llegan al Ministerio de Asuntos Exteriores francés son numerosísimas. Citemos sólo a modo de ejemplo un informe secreto remitido desde Milán que afirma que existe en Italia una gran actividad militar con vistas a un posible conflicto bélico contra Francia y explica en qué sentido podría colaborar España:

"El Estado Mayor italiano parece haber elaborado, de acuerdo con los Almirantazgos de los dos paises, un plan especial de operaciones que sólo sería conocido por muy contadas personas. Ciertos oficiales superiores italianos valoran mucho la posible acción militar de España. Si la intervención activa de los españoles consiguiese retener a las fuerzas francesas en el frente pirenaico, fomentar sublevaciones en Argelia y Marruecos, y entorpecer las comunicaciones por mar con sus colonias africanas, España sería un gran apoyo para la victoria de los ejércitos

\footnotetext{
22 Paulucci a Mussoliri. Madrid, 14 de enero de 1924. MAE (Roma, Política, b. 1589.

${ }^{23}$ Corbin a Poincaré. Madrid, 22 de noviembre de 1923. ADMAE (Paris), 60.
} 
italianos: La duración de la guerra no podria ser muy larga si Francia no puede disponer de sus reservas de hombres" 24 .

La atmósfera de inquietud en Francia hace propicia la propagación de pretendidas copias de convenios italo-españoles ${ }^{25}$ que algunos informadores se dedican a vender a los franceses. Sorprende que estos textos, que contienen muchos datos inverosímiles, de fondo y forma, que invalidan a simple vista su autenticidad, merezcan tanta atención por parte de los embajadores en Roma y Madrid, que se dedican a analizarlos escrupulosamente y a escribir extensos informes dando las razones por las que los consideran "muy sospechosos". Sin duda no hubiera debido merecer tanto papel y quebraderos de cabeza un texto, por ejemplo, en el que al dictador español se le llama "S.E. el Marqués Primo de Rivera" y que, en el anexo titulado "disposiciones para el Mediterráneo" menciona a las Palmas por confusión con Palma de Mallorca. La conclusión es que los convenios que circulan son falsos y los rumores de colaboración militar deben tomarse con toda clase de reservas, si bien el ministro de la Guerra cree que pertenecen también al terreno de la más pura especulación ${ }^{26}$. Lo único de lo que parece tener confirmación el Gobierno francés a estas alturas es de que Mussolini ha intentado impulsar conversaciones con Primo de Rivera para llegar a traducir la concordancia de intereses manifestada por ambos Gobiernos en un documento concreto, y que el dictador español ha dado marcha atrás en sus efusiones y ardor con respecto a Italia y no ha firmado ningún acuerdo por el momento. Pero la posibilidad de que se configure una entente italo-española sigue existiendo y, sin exagerar el peligro que ésta podría representar para Francia, tanto Fontenay, desde Madrid, como Barrere, desde Roma, proponen remedios para evitar que ese entendimiento se materialice. Ambos consideran que la iniciativa proviene de Mussolini y que la amenaza sólo sería temible en caso de conflicto bélico, en el que Francia se expondría a un corte de sus vitales

\footnotetext{
${ }^{24}$ Informe Secreto sobre la situación política y militar de Italia. Milán, 27 de enero de 1924. ADMAE (París), N. ${ }^{\circ} 60$.

${ }^{25}$ Sobre el supuesto convenio militar, véase: Ministro de Asuntos Exteriores y Presidente del Consejo a Embajadas francesas de Madrid y Roma y al ministro de la Guerra. París, 24 de enero de 1924. Y las respuestas de Corbin (Madrid, 2 de enero de 1924), Barrere (Roma, 7 de febrero de 1924, N. ${ }^{\circ}$ 65) y ministro de la Guerra (París, 16 de febrero de 1924, N. ${ }^{\circ} 1210$ ), ADMAE (París), N. ${ }^{\circ}$ 60. Sobre supuestos convenios marítimos, véase: ministro de Marina a Poincaré. Paris, 6 de febrero de 1924, N. ${ }^{\circ}$ 215. Barrere a Poincaré. Roma, 7 de febrero de 1924, N. ${ }^{\circ}$ 64; Roma, 3 de marzo de 1924, N.o 128 ("A propósito de un supuesto convenio naval italo-español"); y Roma, 29 de abril de 1924, N. 258 ("Relaciones italo-españolas y proyectos navales italianos").

${ }^{26}$ Sobre pedidos españoles a Italia de material naval y aéreo y opinión del ministro de la Guerra francés sobre diversos proyectos militares italianos con apoyo de España, véase: ministro de la Guerra a Poincaré. París, 6 de febrero de 1924. ADMAE (París), N. ${ }^{\circ} 60$.
} 
líneas de comunicación con su imperio africano. Pero mientras Barrere aboga por los métodos de conciliación y transacción con Italia, Fontenay opina lógicamente que es a España a la que hay que tratar de contentar. Barrere se lamenta de que, en el momento de la Conferencia de Tánger, Francia no aceptase la admisión de Italia a cambio del compromiso italiano de apoyar el proyecto francés de estatuto para la ciudad:: "Esta concesión formal, que no hubiese introducido a Italia en Africa del norte sino sólo en una sala de conferencias a punto de cerrarse para no volverse a abrir, nos hubiera preservado contra las tendencias que inmediatamente después dieron un significado especial a la vista de Alfonso XIII a Roma" ${ }^{27}$. Concesiones de este género son las que debe dar Francia para que sus relaciones con Italia mejoren "lo suficiente para no temer que ella busque formar partido contra nosotros con España". Por su parte, lo que propone Fontenay es una política de cooperación amistosa con el Gobierno español en Marruecos, tema central que domina las relaciones hispano-francesas una vez resuelto (aunque sólo temporalmente) el contencioso de Tánger. "Francia debe esforzarse por disipar los malentendidos que alejan de ella al Ejército español, dueño en el momento actual de los destinos de este país", "se debe dar a España la impresión de que Francia la considera una entidad apreciable, aunque sólo sea para halagar su amor propio" ${ }^{28}$. A modo de inciso podemos llamar aquí la atención sobre el tono desdeñoso con que se refiere a España el propio Fontenay, defensor de una política francesa de amistad y cooperación con nuestro país. 'En otro de sus telegramas dice por las mismas fechas (y baste como ejemplo): "El Gobierno italiano conoce perfectamente el verdadero valor militar y naval de España, pero con gran destreza confiere a esta Corte y a este pueblo la ilusión de verse tratados como potencia importante que puede desempeñar un papel èn los acontecimientos mundiales que se avecinan. Nos bastaría, creo yo, actuar ante España de la misma forma, dándole la impresión de que la tenemos en cuenta, de que nos interesamos por ella y acaso así pudiéramos impedir que se convirtiese en el juguete y en el instrumento de las peligrosas intrigas del fascismo" ${ }^{29}$. El desdén de Francia, concretamente con respecto a la acción española en Marruecos, crea en España y sobre todo en el Ejército un sentimiento de orgullo herido que -independientemente de que carezcan de base real muchas de las acusaciones españolas de que Francia contribuye a sus fracasos en Marruecos - viene a aña-

\footnotetext{
${ }^{27}$ Barrere a Poincaré. Roma, 17 de abril de 1924, N. ${ }^{\circ}$ 228: "A propósito de los informes de nuestro embajador en España sobre la política mediterránea de este país y sobre una entente italo-española". ADMAE (París), N. 60.

${ }^{28}$ Fontenay a Poincaré. Madrid, 29 de marzo de 1924: "De qué modo la cuestión de Marruecos puede convertirse en una cuestión mediterránea". ADMAE (Paris), N. ${ }^{\circ} 54$ (Espagne: Rélations avec la France, 1924-1925).

${ }^{29}$ Fontenay a Poincaré. Madrid, 8 de abril de 1924. ADMAE (Paris), N. ${ }^{\circ} 60$.
} 
dirse a otros diversós fáctores, algunos de raíz muy antigua, delos que resulta un estado de ánimo anti-francés muy generalizado y que Fontenay califica con preocupación de "enfermizo". El embajador francés cree que es necesario que su país se esfuerce por demostrar que "quiere el mantenimiento del pabellón español en el Rif", aunque sabe qụe la forma de probar la buena fe de Francia no puede ser la de una colaboración militar: Francia no puede exponerse con "una campaña de este género a levantar contra ella a la opinión de las poblaciones musulmanas que le son fieles en Marruecos"; además, "los efectivos de que dispone en Marruecos no bastarían para llevar a cabo pronto y con éxito una operación que debiera efectuarse rápidamente" $\mathrm{y}$, en fin, "cualquiera que fuese el resultado, los españoles nunca se lo perdonarían a Francia" ${ }^{30}$. Pero hay una alternativa, siempre según Fontenay, para procurar un acercamiento entre los Gobiernos de París y Madrid y evitar así que este último "se comprometa imprudentemente y por despecho en la aventura a la que querría arrastrarlo Mussolini", y es otro tipo de cooperación (que Fontenay califica de "simpática"), "que no implicaría ninguna medida bélica efectiva y se limitaría a vigilar severamente las fronteras de tierra y mar, a impedir el contrabando y el reclutamiento de tropas. Actitud que se podría, mediante laobservancia de las normas, conciliar con la neutralidad" ${ }^{31}$. Su opinión es que la única forma realmente eficaz de disuadir a los españoles de desempeñar "un papel ingrato" hacia Francia es actuar amistosamente en Marruecos y calmar las prevenciones de los cuerpos de oficiales. Fontenay manifiesta reiteradamente la misma idea en sucesivos informes a Poincaré enlos meses de marzo y abril de 1924, en vísperas del viaje de los soberanos italianos y de Mussolini a España, en devolución de la visita de noviembre anterior: "La causa que defiendo con insistencia es grave: se trata de impedir que España se vuelva contra nosotros y se enfeude con la Italia de Mussolini. Los monarcas italianos van a venir en junio a Madrid y el dictador traerá un tratado listo para la firma. ¿Qué estamos dispuestos a hacer para evitar que España caiga en la trampa?" 32. Había que contar, además, con el malhumor de Alfonso XIII en relación con Francia del que daba ostensibles muestras, acusándola de llevar a cabo una "guerra sorda" contra España en Tánger y Marruecos. El rey consideraba la actitud del Gobierno francés con respecto a los intereses españoles en el norte de Africa como una ofensa personal: "Vds - le decía al embajador - no me han comprendido, no me han apoyado. No he obtenido ninguna satisfac-

\footnotetext{
${ }^{30}$ Fontenay a Poincaré. Madrid, 29 de marzo de 1924, doc. cit.

${ }^{31}$ Fontenay a Poincaré. Madrid, 25 de marzo de 1924: "El papel de España en Marruecos". ADMAE (París), N. ${ }^{\circ} 54$.

${ }^{32}$ Carta particular que Fontenay dirige al jefe de gabinete de Poincaré. Madrid, 8 de abril de 1924. ADMAE (París), N. ${ }^{\circ} 54$.
} 
ción, no digo de orden material sino siquiera de orden moral. ¿Por qué no reconocer a España su independencia en sus posesiones marroquíes? Mi país tendría así una satisfacción, y ésta no les costaría a Vds. nada. (...) La política de Francia ha sido despiadada en lo que a mí concierne. No se asombre Vd, pues, de encontrar en la población, en el Ejército, un sentimiento no disimulado de amargura, de decepción, con respecto a Francia" ${ }^{33}$. En cuanto a la reciente solución dada al asunto de Tánger, había supuesto para el monarca una gran desilusión que le había llevado, al parecer, a un total escepticismo sobre los buenos deseos de Francia hacia España ${ }^{34}$. Aparte de las audiencias concedidas a los representantes diplomáticos franceses, en las que no oculta desde luego su irritación por la "tremenda ingratitud" de Francia, el soberano muestra signos visibles de su estado de ánimo en otras ocasiones, por ejemplo, con su ausencia durante un ciclo de conferencias de jurisconsultos franceses en Madrid cuando, sin embargo, se había hecho creer que asistiría y sin siquiera recibir después a los conferenciantes. Tampoco realizó su previsto viaje a Burdeos, "a pesar de que se sabe cuán agradable le es hacer este viaje". Sin duda el momento puede parecer muy adecuado a Mussolini para tratar de seducir al rey español. La conclusión de Fontenay es clara: "Ocupémonos de España y sin tardar, porque interesa impedir la firma del tratado con Italia (...). ¿Qué podríamos proponer al rey Alfonso XIII para tomar ladelantera a Mussolini?: Ofrecerle un pequeño pacto de garantía reciproca de nuestras posesiones en Africa del norte, mediante el cual, sin comprometernos demasiado, llegaríamos a mantenerle a nuestro lado y a conservar a nuestra disposición el paso indispensable que España constituye para nuestra aviación, sin hablar del abastecimiento de minerales, tan necesario en caso de guerra" ${ }^{35}$. Sin embargo, la respuesta de Poincaré a laestrategia propuesta por Fontenay es contundente: le agradece sus consideraciones pero le pone en guardia contra los "inconvenientes gravísimos" que tendría la aplicación de su propuesta. De hecho, el mariscal Lyautey, que en esta época se encargaba de todos los asuntos del Marruecos francés, consideraba absolutamente imposible cualquier tipo de colaboración oficial con España, por poco importante que ésta pretendiera ser, ya que inevitablemente trascendería y sería conocida, poniendo así en peligro la seguridad

\footnotetext{
${ }^{33}$ Fontenay a Poincaré. Madrid, 1 de mayo de 1924: "Conversación con el rey Alfonso XIII". Véase también conversación del rey con el agregado militar francés, Comandante Cuverville. Madrid, 31 de diciembre, informe dirigido al ministro de la Guerra. ADMAE (París), N. ${ }^{\circ}$

${ }^{34}$ Fontenay a Poincaré. Madrid, 2 de abril de 1924, N. ${ }^{\circ} 226:$ :Posible transformación del papel que puede jugar España". ADMAE (Paris), N. 60.

${ }^{35}$ Carta particular de Fontenay al jefe de gabinete de Poincaré, doc. cit.
} 54. 
de la zona francesa ${ }^{36}$. Para Lyautey está claro que los marroquíes odian y desprecian profundamente a los españoles, de forma que si supieran que existía una colaboración entre Francia y España se sentirian traicionados y probablemente se rebelarían también contra los franceses. Poincaré, lógicamente influido por el criterio de Lyautey, cree que la propuesta de Fontenay, "cualquiera que fuera la manera en que se tratase de limitar su alcance, correría el riesgo de arrastrar a Francia a una vía peligrosa y comprometer los resultados tan felices de la prudente política proseguida en Africa del norte por el Gobierno, gracias a la valiosa colaboración del mariscal Lyautey". El presidente del Consejo francés desea mantener las mejores relaciones posibles con España, pero sobre la base ya existente, y recuerda al embajador las garantías que ha dado Primo de Rivera de no adquirir compromisos que, ni siquiera en apariencia, se dirijan contra Francia. En su respuesta a Fontenay, acaba diciendo: "No pido otra cosa que fortalecer la amistad (entre Francia y España) mediante buenos procedimientos recíprocos en toda la medida compatible con nuestros intereses esenciales, pero ir más allá sería correr un riesgo mayor, sin duda, del que entrañaría el peligro, hasta ahora hipotético, de una alianza entre Italia y España" ${ }^{37}$.

\section{LOS REYES ITALIANOS DEVUELVEN LA VISITA}

En estas circunstancias, este nuevo acontecimiento en las relaciones hispano-italianas se presenta como otro momento de inquietud para Francia. Sin embargo, a medida que se acerca la fecha del viaje, se comprueba que el ambiente en que éste se prepara no es ni mucho menos el mismo que el existente en 1923. Si se comparan los artículos de la prensa española relativos a la inminente visita de los soberanos de Italia con los publicados en vísperas del viaje de Alfonso XIII a Roma, se aprecia una evidente diferencia $y$, desde luego, los franceses son los primeros en advertirla. Mientras aquéllos fueron numerosísimos y muy entusiastas, comentando efusivamente sus repercusiones, ahora únicamente se habla de horarios y programas de actividades y, en general, la noticia tiene escaso eco. Sólo El Debate se dolía de tal silencio y exhortaba a toda la prensa del país a recordar a la opinión pública la significación del acontecimiento y la necesidad de "renovar el gran esfuerzo llevado a cabo por la prensa italiana en

\footnotetext{
${ }^{36}$ Véase: mariscal Lyautey, Comisario Residente General de Francia en Rabat, al ministro de Asuntos Exteriores. Fez, 22 de marzo de 1924, N. ${ }^{\circ}$ 538. Véase también: Lyautey, nota privada para el comandante de Cuverville. Rabat, 4 de marzo de 1924. ADMAE (Paris), N. $\circ 54$.

${ }^{37}$ Poincaré a Fontenay. Paris, 18 de abril de 1924. ADMAE (París), N. ${ }^{\circ} 60$.
} 
noviembre pasado para preparar la entusiástica acogida que les hicieron en Roma a los reyes de España" ${ }^{38}$. Es muy posible que, en parte, la actitud de la prensa se debiera, al menos en lo que se refiere a los periódicos liberales, a una respuesta frente a la censura impuesta por el Gobierno y que llegó a hacerse muy corriente en los años de la Dictadura, para la indignación de Primo de Rivera, esto es, silenciar, no hacer referencia alguna, a noticias o informaciones cuya difusión deseaba el dictador. Pero, en gran medida, la carencia de comentarios sobre la visita era también consecuencia del escaso interés político que tenía y que resultaba evidente: era solamente una devolución de una visita anterior. Para empezar, Mussolini había disculpado su ausencia en Madrid con una carta al dictador español en la que aludía a la necesidad de permanecer en Roma para organizar los trabajos de la nueva Cámara, en los que "es indispensable", dice, "mi continua y asidua participación" ${ }^{39}$. De hecho, sin embargo, la razón fundamental de Mussolini es que es consciente de que no existe una voluntad clara en el Gobierno español de acceder a la firma del tratado que él ha propuesto $y$, ante la perspectiva de una visita simplemente protocolaria y de cortesía, sin resultados prácticos útiles, prefiere no ir a España. El embajador francés interpreta correctamente la decisión del Duce, y su conversación con el conde de Romanones - que acaba de regresar de Italia - no hace más que confirmarle en su idea. Según Romanones, los franceses no tienen nada que temer puesto que, aunque estaba claro que Mussolini había tratado de comprometer al Gobierno español y arrastrarle quizá a graves aventuras, también era cierto que éste no había respondido a las insinuaciones de que había sido objeto. Romanones había añadido: "Por eso es por lo que Mussolini no vendrá a Madrid para acompañar a los Soberanos de Italia. Sabe ya que no obtendrá nada y juzga por consiguiente inútil molestarse" ${ }^{40}$.

Si algún periódico, como El Debate, pretendía dar relieve a la visita de los reyes italianos era para agradar al régimen de Mussolini - del que muy probablemente recibía subvenciones - y también al de Primo de Rivera el cual, independientemente de su actitud con respecto a las propuestas de alianza mediterránea de Mussolini, deseaba mantener muy amistosas relaciones con Italia. En su defensa del acercamiento italo-español resulta cuxioso que El Debate pase por alto el asunto de las desavenencias entre el Quirinal y el Vaticano que, sin embargo, era el motivo de que el Nuncio Monseñor Tedeschini hubiera desaparecido discretamente de Madrid 15 dias antes de la visita de los soberanos. Efectivamente, el Nuncio Apostó-

\footnotetext{
${ }^{38}$ El Debate, 4 de junio de 1924.

${ }^{39}$ Carta fechada en Roma, el 31 de mayo de 1924. MAE (Roma), Política, b. 1589.

${ }^{40}$ Fontenay a Poincaré. Madrid, 11 de mayo de 1924: "Conversaciones con el conde de Romanones". ADMAE (París), N. 60.
} 
lico no asistió a las fiestas y actos en honor de los reyes de Italia y su ausencia debió parecer sospechosa al público español que quizá pensó que, a pesar de todo lo que le habían contado sobre las buenas relaciones entre el Estado italiano y la Santa Sede, que habian permitido al rey Alfonso XIII viajar a Roma, subsistía algo poco claro, desde el momento en que el Nuncio se había abstenido de estar presente en la recepción real. Como observaba Fontenay, el Nuncio ocupaba en España un lugar que no se podía comparar al de ningún otro representante extranjero y su ausencia no podía pasar inadvertida ${ }^{41}$.

La duración de la visita se redujo en relación con lo previsto en un principio. Los reyes, acompañados por el príncipe heredero, el almirante Thaon de Revel y el jefe del gabinete de Mussolini (y yerno del embajador italiano en Madrid), llegan el día 6 de junio a Valencia y del 7 al 11 realizan su estancia en Madrid. Durante estos días, esta noticia no ocupará el primer plano de las informaciones en la prensa italiana que es reservado al drama del que ha sido víctima el diputado socialista Matteoti y a sus consecuencias políticas y, según Barrere, "el público sólo ha leído distraidamente el detalle de las fiestas dadas en Madrid y Barcelona en honor de los reyes de Italia" ${ }^{42}$. En Madrid, un periódico publicaba una vez finalizada la visita una caricatura que representaba a un trapero cargado con un saco lleno de banderas y gallardetes de los empavesados con que se habían adornado las calles con motivo de la estancia de los reyes. Esta caricatura resumía bastante bien la impresión dejada en España por este viaje, que no había suscitado entusiasmo.

A pesar de todo, el embajador francés había tenido que realizar enormes esfuerzos, al parecer, para contrarrestar el formidable trabajo - muy comentado en los círculos diplomáticos - al que se había entregado el embajador italiano Paulucci que, en palabras de Fontenay, se había lanzado a un verdadero "asalto" sobre el dictador español para lograr la firma del acuerdo. Por su parte y según propia confesión, quizá algo "inflada", Fontenay había hecho otro tanto pero en sentido opuesto: "Durante todas las fiestas, esta fue mi preocupación (la posible firma del tratado de alianza italo-español) y hasta el último momento no cesé de acosar al general Primo de Rivera y de ponerle en guardia contra la seducción italiana, apoyando su buena voluntad y alentando su resistencia. Todo me lleva a creer que he ganado el pleito y que, a pesar de la excepcional presión ejercida

\footnotetext{
${ }^{41}$ Fontenay a Lefebvre du Prey, ministro de Asuntos Exteriores. Madrid, 12 de junio de 1924: "Visita a Madrid de los soberanos italianos. No hay tratado de alianza". ADMAE (Paris), N. 61.

${ }^{42}$ Barrere al ministro francés de Asuntos Exteriores. Roma, 18 de junio de 1924, N. ${ }^{\circ} 332$ : "El viaje de los soberanos italianos a España y la prensa". ADMAE (París), N. ${ }^{\circ} 61$.
} 
sobre él durante toda la presencia de los soberanos italianos, el marqués de Estella ha permanecido inconmovible y fiel a la promesa que me había hecho" ${ }^{43}$. Y cuando todavía quedaban dos días de estancia de los reyes en España, escribía en el mismo sentido: "Me alegra comprobar que los consejos de prudencia que he multiplicado estos últimos tiempos cerca del presidente y de los diferentes miembros del Directorio hayan dado su fruto. Me dicen que los italianos están de muy mal humor. Hace falta ganar todavía 48 horas (...). Hay que alentar sobre todo al presidente a que persevere en su resistencia" ${ }^{44}$. Una vez superada la prueba de la visita real, Fontenay va a ver a Primo de Rivera para obtener de él datos precisos sobre el desarrollo de los acontecimientos: "He hecho al marqués de Estella la pregunta: Ahora que todo ha terminado, ¿puede $\mathrm{Vd}$. afirmar que no ha firmado nada con los italianos? Su respuesta ha sido clara: 'Absolutamente nada' ¿Por qué dudar de mí? Ya se lo había dicho, ahora tengo mis propias convicciones sobre esta cuestión y nada hará que me desvie de ellas. Quiero conservar para mi pais toda su independencia y mantener con Francia, Inglaterra y Portugal las mejores y más confiadas relaciones". "Yo añadí - sigue diciendo Fontenay - que, sin embargo, sabía cómo había sido requerido y acosado, a lo que el general respondió, levantando los brazos en un gesto expresivo: '¡Y de qué manera!'. Insistí, por último, sobre otro punto y le hice esta pregunta: 'Pero, en fin, ¿qué es lo que querían?'. El marqués de Estella tuvo un momento de vacilación y después, resueltamente, gritó: 'iLA HEGEMONIA!, y España no tiene que ayudarles a conseguirla'" ${ }^{45}$. No son estas las únicas declaraciones de Primo de Rivera que Fontenay transmite a su Gobierno. Cuando el embajador fue a dar las gracias al dictador por las muestras de simpatía y amistad expresadas a Poincaré con motivo de su abandono del poder tras la crisis política de Francia, Primo de Rivera "declaró que había querido entregarse a una manifestación de sus sentimientos hacia Francia en el momento en que, aprovechando la presencia de los soberanos italianos en Madrid, se dirigía contra él una violenta y suprema coacción con objeto de arrancarle la firma de un tratado con Italia". "Me resisto - dijo Primo a Fontenay - y no firmaré (...) España ha podido permanecer neutral y todo nos aconseja y nos obliga a perseverar en esta actitud. Además, no quiero hacer nada que pueda alterar nuestras relaciones con Francia" ${ }^{46}$. En otra ocasión

\footnotetext{
${ }^{43}$ Fontenay a Lefebvre du Prey, doc. cit. Sobre esfuerzos de Fontenay por confirmar que no se ha firmado acuerdo alguno, véase: Fontenay a Herriot. Madrid, 17 de julio de 1924, N. ${ }^{\circ}$ 426: "Nueva prueba de que el sueño de Italia de concertar una alianza con España no se ha realizado". ADMAE (París), N. ${ }^{\circ} 61$.

${ }^{44}$ Fontenay a Lefebvre du Prey. Madrid, 11 de junio de 1924. ADMAE (París), N. ${ }^{\circ} 61$.

${ }^{45}$ Fontenay a Lefebvre du Prey. Madrid, 13 de junio de 1924, n. ${ }^{\circ} 419$ : "Declaraciones precisas del presidente del Directorio". ADMAE (Paris), N. ${ }^{\circ} 61$.

${ }^{46}$ Fontenay al ministro de Asuntos Exteriores. Madrid, 11 de junio de 1924. Véase también:
} 
Primo comenta al embajador: "Le veía a Vd. todas las tardes aparecer a mi lado diciéndome al oido: „No firme! Se ha salido Vd. con la suya" 47. Fontenay considera que es necesario reconocer el buen sentido y la simpatía por Francia de que da muestras Primo de Rivera, y cree que es preciso sacar provecho de esta excelente disposición, "ocupándonos de ahora en adelante más activamente de España". Ahora más que nunca cree el embajador que Primo de Rivera no desea una estrecha entente con Italia que comprometa sus relaciones con Francia. En estas fechas sus comentarios giran en torno a estos temas: los vagos proyectos que fueron discutidos en Roma en noviembre de 1923 han desaparecido ante el buen juicio del Gobierno español, cuyo jefe ha disipado sus dudas sobre las ambiciones, demasiado grandes, que ha podido observar en Mussolini. Ha comprendido el peligro que ello entraña, se ha dado cuenta sobre todo de que España no tenía por qué buscar comprometerse en arriesgadas empresas para las que ni su Marina, ni su Ejército, ni sus finanzas, ni su opinión pública están preparados. No hay en España fascistas ávidos de conquistas y engrandecimientos territoriales. Primo de Rivera sólo ansía poner fin a la resistencia de Abd el-Krim y, en el interior, extirpar los principales abusos que han conducido al país al estado en que se encuentra. Por lo demás, se desea vivir en paz con los vecinos, sobre todo con Francia, "cuya vecindad se vuelve cada día más cercana, más íntima, gracias al desarrollo de la vida económica e intelectual".

El conde Peretti della Rocca, que sustituye a Fontenay al frente de la Embajada francesa en los últimos días de diciembre de 1924, compartirá con su predecesor la opinión de que, aunque no son desde el punto de. vista francés verdaderamente inquietantes las tentativas italianas de concertar una alianza política con España, porque el Gobierno de este último país es poco propicio a correr los riesgos que ella comporta, sería prudente aun así no dar motivos para que éste escuche y pueda en algún momento dejarse arrastrar por determinadas propuestas de Mussolini, movido por el descontento o la frustrasión con respecto a Francia. El nuevo embajador francés fue recibido en Madrid con cierta aprensión, con cierto temor a que resultara intratable. En la presentación de credenciales, no pasó inadvertida la reserva y la rigidez del discurso del rey. Sin embargo, en contra de lo que se esperaba, Peretti adoptó desde el principio una actitud de simpatía hacia el Gobierno español. Por su parte, el embajador italiano, Paulucci, a quien habian producido gran depresión los resultados

el ministro de Asuntos Exteriores a Guerra, Marina y mariscal Foch. Paris, 18 de junio de 1924: "Declaraciones de Primo de Rivera". ADMAE (Paris), N. 54.

${ }^{47}$ Fontenay a Herriot. Madrid, 10 de julio de 1924, N. ${ }^{\circ} 499$ : "Conversaciones con el general Primo de Rivera". ADMAE (Paris), N. ${ }^{\circ} 54$. 
negativos de la visita de los soberanos de su país a Madrid, se encontraba frente a su Gobierno en una posición un tanto debilitada como consecuencia de su fracaso en la política de "captación" de España. Parece que a raíz de este fracaso, Paulucci pensó en retirarse si bien prolongó su permanencia en el puesto, según se decía, en razón del elevadísimo sueldo que percibía y porque podía permitirse el lujo de estar fuera todo el tiempo que quisiera, quizá porque - como él mismo afirmaba - era el único embajador fascista (llevaba siempre la insignia fascista en el ojal) y quizá también por la relación de parentesco que le unía con el jefe de gabinete de Mussolini. En cualquier caso, durante 1925 pasó gran parte del tiempo fuera de España hasta el punto que la sociedad madrileña llegó a considerar que, de hecho, la embajada italiana no existía.

\section{EL PELIGROSO AÑo 1926: LA FIRMA DEL TRATADO DE AMISTAD ITALO-ESPAÑOL}

En el verano de 1925, ante la ofensiva de Abd el-Krim contra la zona francesa de Marruecos, el Gobierno francés, en contraste con la que venía siendo su política hasta entonces, decide iniciar conversaciones con España para acordar una acción conjunta frente al común enemigo, enviando primero a Malvy y luego a Pétain a Madrid. Durante el período de gestación de la colaboración hispano-francesa en Marruecos y durante su desarrollo, la prensa española se olvida prácticamente de Italia y señala que el acuerdo franco-español supone un cambio decisivo en Marruecos y en el Mediterráneo.

Mussolini, a pesar de que no tenía ya grandes esperanzas de que el Gobierno español accediese a sus deseos -Primo de Rivera había manifestado a Paulucci que no creía que mereciese la pena sellar mediante un pacto concreto la platónica identidad de los intereses italianos y españoles - seguía todavía intentando la firma de un acuerdo o, por lo menos, hacía lo posible por dar la impresión de que existían negociaciones entre los dos Gobiernos. Desde principios de 1926 se realizaron una serie de visitas de personalidades italianas a Madrid. Además, con ocasión del viaje de Primo de Rivera a Valencia, el embajador y el agregado militar italianos fueron también allí y participaron en algunas manifestaciones en honor al jefe del Gobierno. Este encuentro no era evidentemente fortuito, "por lo menos por parte de mi colega italiano", escribia Peretti della Rocca a Briand. Pero más significativo era para los franceses que el agregado militar de Italia hubiera logrado ser invitado por el Estado Mayor español a visitar las obras emprendidas para el establecimiento de una base de hi- 
droaviones cérca de la desembocadura del Ebro. Con respecto a los rumores de que Italia había manifestado a España sus deseos de participar en los acuerdos derivados de la pacificación del Rif, el Gobierno francés había tenido que dejar claro que se oponía tajantemente a la intervención italiana en las conversaciones.

Los propósitos italianos parecieron verse coronados por el éxito cuando se supo que españoles e italianos habían firmado en Madrid un tratado de amistad, el 7 de agosto de 1926. El riguroso secreto en que se habian mantenido las negociaciones (ni el Gobierno italiano ni el español habían anunciado por anticipado su intención de suscribir un tratado), la falta de información precisa sobre el contenido del mismo, por no haber publicado los países signatarios inmediatamente el texto del acuerdo, y la época de vacaciones oficiales $y$, por tanto, de escasa actividad gubernativa, en que se había firmado, eran razones que, junto a otras todavía mucho más inquietantes que se sumaron a éstas enseguida, produjeron considerable alarma y llevaron a la prensa extranjera a especular sobre su posible significado. Esas otras razones eran la gran importancia que la prensa fascista parecía atribuir al tratado como medio eficaz de contrarrestar "la hegemonía francesa en el Mediterráneo occidental" $y$, sobre todo, el hecho de que España presentase oficialmente su nueva reivindicación sobre Tánger tan sólo dos semanas después de la firma de este tratado y que, además, Primo de Rivera enviase la nota en la que hacía esta reclamáción, no únicamente a Londres y París sino también a Roma, cuando, sin embargo, Italia no figuraba entre las potencias firmantes del estatuto de 1923. Todo esto hizo sospechar que era un tratado de amplio alcance y creó suspicacias y recelos en relación con la posible existencia de cláusulas secretas. El temor que abrigaban los comentarios de ciertos periódicos europeos -y concretamente franceses - residía en la suposición de que España, a cambio de conceder ventajas a Italia en un eventual conflicto italo-francés - no era la primera vez que se insinuaba que España podía haber accedido a que Italia utilizase las islas Bareares como base militar - lograba que Mussolini apoyara decididamente su reivindicación de Tánger. En general, la prensa europea se lamentaba del regreso a la diplomacia secreta, contraria a los principios de la Sociedad de Naciones.

Desde luego, en el verano de 1926 y de nuevo por la cuestión de Tánger, se produce un giro, y la posición francesa con respecto a España, que parecía estar ya asegurada a raíz de la colaboración en Marruecos, parece resentirse de nuevo al tiempo que el Gobierno italiano gana otra vez ascendiente e influencia. "Los éxitos obtenidos en común sobre el Uarga en la primavera de 1926 no han bastado al parecer para sellar un acercamiento definitivo entre Francia y su vecina", comenta el embajador 
francés ${ }^{48}$. Lo que ha sucedido es que Primo de Rivera ha obtenido en septiembre del año anterior el mayor éxito de su mandato con el desembarco en Alhucemas. Durante 1926 esta victoria se consolida con la pacificación de la zona española de Marruecos. El dictador se siente exultante y deseoso de nuevos éxitos que eleven el prestigio internacional de su patria y su propio prestigio personal. Cree llegado el momento de emprender una política exterior más activa y, concretamente, de dar satisfacción a sus dos grandes aspiraciones desde hace tiempo: el otorgamiento a España de un puesto permanente en el Consejo de la Sociedad de Naciones, y la inclusión de Tánger en la zona española. El Gobierno organiza una campaña a favor de estas demandas cuyo resultado es un absoluto respaldo por parte de la opinión pública.

Ya el 17 de abril, el ministro de Estado Yanguas había planteado nuevamente la cuestión de Tánger en un discurso pronunciado en la Real Academia de Jurisprudencia, coincidiendo con una campaña en la prensa sobre el fracaso del estatuto. El 25 de agosto, España hacía oficialmente la reclamación de que la ciudad fuera incluida en la zona española. La sempiterna reivindicación española fue rechazada una vez más por Francia e Inglaterra ${ }^{49}$ pero, sin embargo, ambas potencias admitieron la necesidad de revisar el estatuto internacional de 1923 que en la práctica había demostrado ser muy imperfecto. La negativa franco-inglesa a satisfacer la demanda española sobre Tánger hacia renacer la amistad de la Dictadura hacia !talia. En palabras de Peretti, "la intriga italo-española se reanuda en 1926 y, de nuevo, con motivo de Tánger" ${ }^{50}$. A los ojos de las Cancillerías europeas, la aproximación a Italia y la petición de Tánger aparecían como dos puntos de una misma estrategia por parte de España. A ello había contribuido Alfonso XIII al hacer alusión a que las buenas relaciones hispano-italianas dejarían sentir su efecto en la favorable actitud de Italia hacia la posición española en el tema de Tánger ${ }^{51}$. El corresponsal de $A B C$ en Roma, Rafael Sánchez Mazas, escribía por su parte que "un Tánger español sería la mejor garantía de la amistad italo-española". Efectivamente,

\footnotetext{
${ }^{48}$ Peretti della Rocca a Briand. Madrid, 16 de noviembre de 1926: "Las tendencias de la política española y la defensa nacional". ADMAE (París), N. ${ }^{\circ} 61$.

${ }^{49}$ Aunque Gran Bretaña juega también un importante papel en la cuestión de Tánger, se trata fundamentalmente de un contencioso entre España y Francia mientras que el problema planteado por la petición española en la Sociedad de Naciones atañe más directamente a Inglaterra. Para el papel desempeñado por Gran Bretaña en ambos asuntos, véase: Javier TUSELL y Genoveva GARCIA QUEIPO DE LLANO: El dictador y el mediador. Las relaciones hispanoinglesas durante la época de Primo de Rivera, CSIC, 1986.

${ }_{50}$ Peretti a Briand. Madrid, 17 de enero de 1927. ADMAE (París), N. ${ }^{\circ} 61$.

${ }^{51}$ Véase: Chamberlain a Charles Wingfield, embajador inglés en Roma. Londres, 4 de agosto de 1926. Tel. N. ${ }^{\circ} 12$, y Charles Wingfield a Chamberlain. Roma, 12 de agosto de 1926. Tel. N. ${ }^{\circ} 677$. PRO,FO 371/11944.
} 
España esperaba obtener el apoyo de Italia para hacer valer con más fuerza su reivindicación pero, como veremos más adelante, Mussolini tenía sus propios proyectos y ambiciones al respecto. En realidad, Primo de Rivera desconfiaba bastante, ya por entonces, de los planes que pudiera albergar Mussolini, pero tenía interés en utilizar la amenaza de una alianza con Italia como forma de presión sobre Gran Bretaña y Francia para lograr que cedieran terreno en la cuestión de Tánger y de la Sociedad de Naciones. Por esta razón, se habian vuelto a abrir las conversaciones hispanoitalianas para la firma de un tratado y en esta ocasión habia llegado a firmarse pero, a pesar del halo de misterio que lo rodeaba y de los rumores sobre cláusulas secretas, lo cierto es que tanto Briand como el Foreign Office, informados por sus respectivos representantes diplomáticos, habían visto con calma la conclusión del tratado. Y es que Primo de Rivera había jugado la baza italiana pero sólo hasta un punto compatible con los intereses de las otras dos naciones mediterráneas, es decir, era un tratado que no comprometía sus relaciones con Francia e inglaterra y, desde luego, muy distinto del que Mussolini hubiese deseado ${ }^{52}$. Movido por un deseo de afirmación de los derechos que creía que correspondían a España como potencia mediterránea, no quería sin embargo que los comentarios se desbordasen y pudiesen dar lugar a roces con París o Londres. De hecho, ante las desmesuradas proporciones que toma el asunto en la prensa europea, en gran medida a instigación de las noticias aparecidas en algunos periódicos italianos, el Gobierno español vuelve a actuar como en ocasiones anteriores, esto es, tratando de calmar los ánimos y quitando importancia a la cuestión. El ministro de Estado hace diversas declaraciones afirmando que el tratado es muy parecido al ya concluido con Suiza -y que ha servido de modelo- y a otros que el Gobierno se propone firmar en el futuro con otros países. Su única peculiaridad - explica- es una cláusula de neutralidad añadida a petición de Italia, por la que cada una de las partes se compromete a observar absoluta neutralidad en el caso de que alguna de ellas sea atacada por otra $u$ otras potencias. Yanguas aseguraba que el tratado contribuía al mantenimiento de la paz general y, concretamente, que España estaría dispuesta a firmar uno semejante con Francia y, puesto que, una vez dado a conocer el texto, los comentarios alarmistas se habían centrado en la posibilidad de que éste no fuera más que el preludio de un acuerdo más importante o bien que existiesen disposiciones no publicadas, también se había visto obligado a insistir en

\footnotetext{
${ }^{52}$ El tratado de amistad, conciliación y arbitraje hispano-italiano, cuya vigencia era de 10 años, no tenía especial importancia política y menos aún militar o naval. Los signatarios se comprometian a someter toda controversia que no fuera resuelta por los medios diplomáticos ordinarios, en primer lugar, a una comisión de conciliación y si ésta fallaba, al Tribunal de Justicia de la Haya.
} 
que estas suposiciones carecían de todo fundamento. En la prensa española, en contraste con lo que sucede en la italiana, hay una notable ausencia de comentarios sobre el tratado. Mientras que Mussolini lo quiere rentabilizar para "impresionar a la opinión francesa y mantener inquieta a la opinión pública internacional" ${ }^{53}-y$ de ahí que la prensa fascista le atribuya mucha mayor importancia de la que en realidad tiene ${ }^{54}$ - Primo de Rivera recurre a la censura para evitar especulaciones infundadas que puedan excitar los ánimos de Francia y Gran Bretaña. Yanguas, en una conversación con el encargado de negocios francés, deploraba los comentarios de la prensa italiana que veian en el tratado "consecuencias políticas que no ha tenido ni puede tener" y aludía a los esfuerzos del Gobierno español para "volver a poner las cosas en su sitio" 55. Por su parte, el embajador francés declaraba: "Persisto en creer que las conversaciones italo-españolas no han concluido en un acuerdo secreto (...) Incluso si pensamos que no debemos tener plena confianza en las declaraciones tan claras que el general Primo de Rivera y el señor Yanguas me han hecho tantas veces, el interés de España es demasiado patente, la prudencia de sus hombres de Estado demasiado sagaz para que podamos creerla sospechosa de haberse comprometido en una alianza política cuyos riesgos se manifiestan más claramente que sus ventajas. Aunque, a veces, el General Primo de Rivera parezca un hombre espontáneo, capaz de sucumbir a una incitación, creo que se sentiría en realidad menos inclinado que cualquier otro jefe de Gobierno a vincular a su país a la suerte de Italia" 56 .

El Gobierno español se presta gustoso por estas fechas a poner énfasis en la gran amistad hispano-italiana siempre que se trate de manifestaciones poco "peligrosas": el ministro de Estado y el embajador italiano se invitan con frecuencia uno al otro, barcos de guerra españoles visitan diversos puertos italianos y se concede a Mussolini la Gran Cruz de la Orden del Mérito Naval, y por su parte dos barcos de guerra italianos llegan a San Sebastián. Todos estos actos y visitas son acompañados de discursos y declaraciones ampulosas y retóricas sobre las excelentes relaciones entre las dos penínsulas latinas ${ }^{57}$. Entre las manifestaciones de simpatía

\footnotetext{
${ }^{53}$ Raffaele Guariglia, Ricordi, pág. 52.

${ }^{54}$ Por lo general, la prensa italiana de oposición se abstenía de comentar el tratado, pero la prensa fascista le atribuía un significado claramente hostil a Francia y, en alguna medida, también a Gran Bretaña. Vèase, por ejemplo, /l Mattino (10 ag. 26), // Lavoro D'ltalia (11 ag. 26) II Secolo (11 ag. 26), La Tribuna (17 ag. 26), y también /I Popolo d'ttalia y Giornale d'ttalia de estas fechas.

${ }^{55}$ Véase: M. De Montille a Briand. San Sebastián, 22 de septiembre de 1926. ADMAE (Paris), N. ${ }^{\circ} 61$.

${ }^{56}$ Peretti a Briand. Madrid, 17 de enero de 1927, doc., cit.

${ }^{57}$ Véase: Roger a Briand. Roma, despachos N. ${ }^{\circ} 453$ y ss. de 5 y 6 de septiembre de 1926.
} 
hacia Italia hay que contar también los comentarios favorables hacia el fascismo, y la censura de críticas y ataques al Gobierno de Mussolini en la prensa española. Al mismo tiempo, sin embargo, el Gobierno de Primo de Rivera rehusa toda injerencia italiana en sus propios asuntos y decisiones. He aqui un significativo ejemplo: ante una muestra de buena voluntad por parte de Francia al ordenar la expulsión de territorio francés de un español exiliado que había insultado gravemente al cónsul de España en Hendaya, Primo de Rivera envió un telegrama al embajador en París, Quiñones de León, para que éste lo transmitiera al Gobierno galo, en el que reconocía la actitud leal y la buena fe de Francia y cuyo último párrafo irritó a Mussolini hasta el extremo de pedir explicaciones al Gobierno español por considerar que estaba calculado para debilitar sus propias protestas ante Francia en lo concerniente a las acciones y conspiraciones de los italianos anti-fascistas en aquel país. El párrafo en cuestión decía: "Nosotros limitamos nuestras quejas al Gobierno francés a un mínimo, puesto que somos totalmente conscientes de la buena voluntad con que ese Gobierno cumple su deber de supervisión de los emigrantes que conspiran, y también porque respetamos el alto espíritu de democracia que Francia y su Gobierno muestran en relación con todos los que gozan de su hospitalidad". A pesar de que, de hecho, Primo de Rivera - que había redactado él mismo estas frases- pretendía llamar la atención del Gobierno francés sobre la diferencia entre sus métodos y los de Mussolini al formular quejas en relación con los respectivos connacionales exiliados en Francia ${ }^{58}$, se sintió muy molesto por la intromisión del dictador italiano al que contestó que no tenía por qué darle satisfacciones toda vez que no existía conexión entre las protestas que España hiciera y las que pudiera formular Italia ${ }^{59}$. El incidente se resolvió discretamente pero dejó claramente una desagradable impresión en el Gobierno español y en Primo de Rivera que, a pesar de su admiración por Mussolini en algunos aspectos, se sentía sin embargo "horrorizado" al comprobar que perdía el control de sus nervios con gestiones intempestivas como ésta, según confesó Yanguas a Montille, encargado de negocios francés ${ }^{60}$. De esta misma conversación se des-

ADMAE (París), N. ${ }^{\circ}$ 61. Véase también: Horace Rumbold a Chamberlain. Madrid, 14 de septiembre de 1926. PRO, FO 371/11945.

58 Tels. de Montille, encargado de negocios de Francia, a Briand, N. ${ }^{0 s} 511$ y 520 , de 10 y 24 de septiembre de 1926, respectivamente. ADMAE (Paris, №. 61. Dos periódicos franceses, el Sud-Ouest de Bayona y el Quotidien habian afirmado que el Gobierno español había exigido al francés medidas drásticas contra los refugiados y había enviado a agentes a perseguirlos en territorio francés. Unamuno y Gasset que residían entonces en Hendaya lanzaron también acusaciones contra la Dictadura con motivo de la expulsión del súbdito español. El deseo de refutar estas acusaciones fue otra de las razones que llevaron a Primo de Rivera a enviar el telegrama.

59 Spain. Annual Report, 1926. PRO, FO 371/12718.

${ }^{60}$ Montille a Briand. San Sebastián, 22 de septiembre, doc. cit. 
prende que, efectivamente, la intención de Primo había sido no sólo mostrar su agradecimiento por la actitud francesa sino marcar ciertas distancias con respecto a Mussolini ante los ojos de Francia y no debía ser ajeno a ello el alboroto que el tratado hispano-italiano había provocado. En la misma tónica estaban sus comentarios al embajador francés sobre la inquietud y asombro que le producian las declaraciones belicosas del Duce en un tiempo en que todos los pueblos estaban ávidos de paz. En contraste con Italia, afirmaba, los únicos deseos y aspiraciones del pueblo español eran, una vez restablecido el orden en el interior, asegurar el normal desarrollo de su comercio, agricultura e industria ${ }^{61}$. Por las mismas fechas, y por deseo imperativo de Primo de Rivera, se suprime la escala en Málaga que tenían previsto efectuar los navíos italianos Pisa y Ferruchio y para los que las autoridades locales habían preparado fiestas. El cambio de programa se debía al parecer a que el dictador español "encontraba las manifestaciones de simpatía hispano-italianas demasiado frecuentes" 62. Por otra parte, en relación con la supresión de la Oficina militar interaliada, también en Málaga, el general Jordana era de la opinión y el Gobierno la compartía - de que había interés en mantenerla, "incluso si su única utilidad fuese, después de todo lo que se ha escrito sobre las consecuencias del tratado de arbitraje hispano-italiano, la de mostrar a la opinión pública que las relaciones franco-españolas son tan íntimas como en el pasado" 63 .

De momento, está claro que el Gobierno español no se atreve a ir más lejos que un simple coqueteo con Italia que pueda llevar a Francia e Inglaterra a hacer a España alguna concesión en las demandas que tiene planteadas. El tratado hispano-italiano no suponía ninguna amenaza real para las tradicionales aliadas de España, y Mussolini no estaba desde luego satisfecho con lo poco que en realidad había conseguido de Primo de Rivera. Ante el revuelo suscitado por el tratado y por temor a provocar susceptibilidades en Francia, el dictador había dado enseguida marcha atrás, apresurándose a dar seguridades al Gobierno francés sobre su lealtad. "España -decía Yanguas al embajador francés- no tiene miras imperialistas de ningún género. Es un país que consiguió mantener la neutralidad durante la Gran Guerra y que seguirá absteniéndose en todo compromiso que pudiera entrañar el riesgo de abandonar su neutralidad en el futuro. No quiere tentar a la suerte y se atiene a sus amistades francesa e inglesa. Ese es el camino recto del que no se apartará para lanzarse a una

\footnotetext{
${ }^{61}$ Peretti a Briand. Madrid, 1 de noviembre de 1926. ADMAE (París), 61.

${ }^{62}$ Montille a Briand. S. Sebastián, 29 de septiembre de 1926. Véase también: teniente de Navio Guieu al jefe de los Servicios de Información del Ministerio de Marina. S. Sebastián, 28 de septiembre de 1926, ADMAE (París), N. ${ }^{\circ} 61$.

${ }^{63}$ Montille a Briand. S. Sebastián, 29 de septiembre de 1926, doc, cit.
} 
política que sólo puede ser una política de aventura" ${ }^{44}$. Por otro lado, por lo que respecta a la decisión de retirada de la Sociedad de Naciones, anunciada pocas semanas después de la firma del tratado con Italia, el Gobierno español no estaba contento con ella y más bien se había visto obligado a tomarla para no defraudar a la opinión pública ni herir el orgullo nacional. A este respecto, el embajador inglés Rumbold escribía a Chamberlain: "No veo signos de resentimiento contra los franceses o contra nosotros en relación con el fracaso de España al no obtener un puesto permanente en el Consejo sino que, por el contrario, me inclino a pensar que los españoles están algo preocupados por el resentimiento que la notificación de su retirada de la Sociedad al cabo de dos años haya podido suscitar en nosotros y en los franceses" ${ }^{65}$. No tardaría mucho Primo de Rivera en buscar y hallar el camino que le permitiera regresar nuevamente al seno del organismo ginebrino. El desafío del verano del 26 a las dos potencias garantes del statu quo en el Mediterráneo había sido, por tanto, un desafío a medias.

\section{7: OTRO AÑO DE TEMORES}

Para Francia y Gran Bretaña, ciertos acontecimientos del año 1927 suponen de nuevo una perturbación y un potencial peligro para el statu quo. A pesar de que en las Cancillerías francesa e inglesa se conocen las reticencias y escasa disposición de Primo de Rivera a embarcarse en aventuras poco claras como la que entraña una alianza política y militar con Italia, son igualmente conscientes de la existencia de factores que favorecen un entendimiento hispano-italiano de esta naturaleza. El Gobierno italiano no deja de aprovechar cualquier oportunidad para incitar a España a situarse a su lado y, sin duda, el descontento español por la actitud intransigente de Francia en las negociaciones sobre Tánger juega a favor de las intenciones italianas.

Las manifestaciones de la amistad entre los dos países se suceden a lo largo del año, si bien se van a concentrar de forma muy especial a finales de octubre y principios de noviembre. La cuestión de Tánger sigue negociándose y, como bien sabe el embajador francés en Madrid, Tánger es la clave del acercamiento del Gobierno español a Italia: "Muchas veces he tenido ocasión de señalar a V.E. el intercambio de gentilezas entre

\footnotetext{
${ }^{64}$ Montille a Briand. S. Sebastián, 22 de septiembre de 1926, doc. cit.

${ }^{65}$ Rumbold a Chamberlain. Madrid, 1 de octubre de 1926, N. ${ }^{\circ} 443$. PRO, FO 371/11945.
} 
Italia y España. Son intermitentes. Si se hacen más raras cuando la cuestión de Tánger no está a la orden del día, se multiplican, por el contrario, cuando la suerte de la zona internacional está en discusión" ${ }^{66}$.

Aparte de inofensivos intercambios de condecoraciones ${ }^{67}$, seproduce un cambio del embajador italiano en Madrid. El marqués Medici del VasceIlo entrega, a su llegada, una carta personal de Mussolini a Primo de Rivera que es leída en el Consejo de Ministros y que, según el análisis de los periódicos, no es simplemente de cortesía. Por otra parte, los discursos intercambiados en la presentación de las cartas credenciales se salen de la banalidad habitual de este género de ceremonias. Al mes siguiente, en mayo, el Gobierno español envía a Aunós, ministro de Trabajo, a la feria de Milán primero y, a continuación, a Roma, para entrevistarse con Mussolini y entregarle una carta de Primo de Rivera cuyo contenido se desconoce. Con este motivo, el embajador español en Roma, conde de la Viñaza, hace una valoración de las relaciones hispano-italianas en el Giornale d'Italia del día 15 que no es muy tranquilizadora para Francia: "Me alegra poder afirmar que a propósito del Mediterráneo, el acuerdo italo-español es perfecto y completo. El problema de Tánger forma parte de este acuerdo, y en los momentos más difíciles de la batalla diplomática por Marruecos, España ha podido contar con el leal y eficaz apoyo de Italia" ${ }^{68}$. A finales de mayo, nuevos comentarios, esta vez a propósito del viaje del infante Alfonso a Bolonia, donde es recibido con toda solemnidad para asistir, en compañía de Víctor Manuel y Mussolini, a la inauguración del estadio deportivo de la ciudad. Pero sin duda es en el corto lapso de tiempo ya señalado - el final de octubre y el comienzo de noviembrecuando se producen una serie de acontecimientos encadenados de carácter más preocupante: la visita de una escuadra italiana a Tánger, el viaje de Alfonso XIII a Nápoles, la creación de un puesto de agregado naval italiano en Madrid...

Aprovechando la celebración del quinto aniversario de la marcha sobre Roma, Mussolini manda desembarcar a finales de octubre una división naval - un crucero y dos destructores - en Tánger, al mando del príncipe

${ }^{66}$ Peretti a Briand. Madrid, 4 de abrii de 1927: "Manifestaciones de amistad hispano-italiana". ADMAE (Paris), N. ${ }^{\circ} 61$.

${ }^{67}$ El Gobierno italiano las concede a cierto número de miembros de la Unión Patriótica, a principios de abril, y la ceremonia de entrega de las cruces da lugar a una manifestación de amistad en la que Primo de Rivera lanza vivos elogios a Mussolini, "hombre genial cuya obra subsistirá a lo largo de los siglos". "En cuanto a mi - prosigue el marqués de Estella - he tenido la suerte de interpretar en España modestamente las mismas aspiraciones de orden y de grandeza...". Por su parte, el Gobierno español condecora a algunas personalidades fascistas.

${ }^{68}$ Giornale d'Italia, 15 de mayo de 1927. 
de Udine que, a su llegada, es objeto de una entusiasta manifestación nacional por parte de la colonia italiana. Es un golpe de efecto, muy acorde con el temperamento del jefe fascista, que produce irritación y malhumor en Europa. La prensa extranjera rechaza este método como medio de llamar la atención sobre las pretensiones italianas. Sin embargo, en España, los periódicos no muestran signos de alarma ante esta imprevista acción en momentos tan significativos - vísperas de la reapertura de la Conferencia hispano-francesa sobre Tánger -, actitud que no pasa inadvertida en Francia y Gran Bretaña. Además de la ausencia de críticas en la prensa, el general Goded va a Tánger expresamente para saludar a las autoridades italianas y asistir a la proyección de una película de propaganda sobre Italia. En un informe llegado al Ministerio de Asuntos Exteriores francés escrito por "un informador generalmente bien informado", se asegura que "el Gobierno español sabía perfectamente cuál seria la emoción que produciría en Europa, y muy especialmente en Francia, la visita reciente de una escuadra italiana a Tánger, a pesar de lo cual el general Goded, jefe del Estado Mayor y segundo del Alto Comisario español en Marruecos, asistió a las fiestas italianas celebradas en esta ocasión, en representación del Alto Comisario, General Sanjurjo" ${ }^{69}$. Coincidiendo también con estos hechos, El Debate publica, el 30 de octubre, un artículo titulado "Solidaridad Mediterránea" 70 que no hace alusión a Tánger pero que manifiestạ su total adhesión a una política exterior española basada en la amistad con Italia y cuya repercusión en el extranjero es enorme.

La prensa europea va a relacionar estrechamente la visita italiana a Tánger y el viaje de Alfonso XIII a Nápoles en los primeros días de noviembre. Se afirma que "en los centros oficiosos españoles" y "en determinados círculos diplomáticos" se atribuye una gran importancia política a este nuevo viaje del soberano a Italia, en el que se tratarán - se dice- los problemas del Mediterráneo y sin duda el tema de Tánger. Estos rumores circulan también por Madrid y, en este sentido, Peretti escribe a Briand: "Está en el ánimo de todo el mundo aquí establecer una relación entre la visita naval italiana a Tánger y el viaje del rey de España a Nápoles, que la

\footnotetext{
${ }^{69}$ Informe: "A propósito de la política exterior de España y el acercamiento italo-español", de un informador generalmente bien informado. ADMAE (Paris), N. ${ }^{\circ} 61$.

${ }^{70}$ Fueron estas palabras, "solidaridad mediterránea", las utilizadas por Mussolini en la dedicatoria de un retrato suyo que regala a El Debate con motivo del quinto aniversario del Gobierno fascista. Primo de Rivera expresará su malestar por este artículo en una nota enviada a la prensa en la que dice: "Se ha dado sin fundamento a dicho artículo en el extranjero un alcance aventurado; se ha dicho fuera de España que tenia carácter oficioso y no es así, ni ha habido por qué suponer tal cosa (...) No cabe complicar al Gobierno, cuyo pensamiento sólo a él compete definirlo..." (El Debate, 6 de noviembre de 1927: "El presidente rechaza el alcance dado en el extranjero a nuestro editorial del domingo").
} 
única razón de parentesco no hacía indispensable" ${ }^{71}$. Aunque, según las notas oficiales, el propósito del viaje del monarca es su asistencia, en calidad de testigo, a la boda de la princesa Ana de Orléans y el duque de Apulia, es inevitable que surjan especulaciones: "El viaje del rey a Nápoles - afirma Peretti en otro despacho- sigue siendo la comidilla. La gente se asombra aquí de que Alfonso XIII se haya molestado en asistir a la boda del nieto del rey de España Amadeo con una princesa de Orléans que sólo es pariente suya muy lejana" ${ }^{72}$. La decisión española de ampliar el programa del viaje, incluyendo la visita a un puerto francés - Bizerta (Túnez)otro inglés - La Valetta (Malta) - y otro español -Mahón (Menorca) con la intención de no despertar las susceptibilidades de Francia e Inglaterra y "contentar a todos" ${ }^{73}$, no consigue su objetivo. Según Peretti, este cambio puede obedecer a una sugerencia italiana, por desear Mussolini ocultar su juego, o bien su finalidad puede ser permitir al rey hacerse una idea precisa, después de haber inspeccionado una base inglesa y otra francesa del Mediterráneo, de la necesidad de un gran puerto militar español en Mahón. En cualquier caso, la visita a Mahón parece cobrar especial significación pocos días después de que el rey haya estado en Italia y habiendo transcurrido además muchos años, más de 20, desde que el soberano no iba a las Baleares. Según los rumores, España quiere hacer de Mahón una base naval de gran importancia ya que éste es uno de los puntos previstos en el acuerdo italo-español. Un sobresalto más, en este ambiente de gran recelo, lo constituye la publicación de un artículo en el Diario Español de Buenos Aires, relativo a la visita del rey a Nápoles y a la solidaridad italo-española en el Mediterráneo, que es reproducido por toda la prensa española. Peretti se pregunta al informar del contenido de este artículo a Briand: "¿Cómo explicar que la censura haya dejado pasar este telegrama en el momento del viaje del rey de España a Nápoles?" ${ }^{74}$. Desde luego, el artículo del órgano de la colonia española de Buenos Aires y periódico oficioso de la Dictadura es una confesión sin disimulo a favor de una política anti-francesa de acuerdo con Italia ${ }^{75}$.

\footnotetext{
71 Peretti a Briand. Madrid, 30 de octubre de 1927: "Viaje de la escuadra italiana a Tánger y del rey de España a Nápoles". ADMAE (Paris), N. 61.

${ }^{72}$ Peretti a Briand. Madrid, 2 de noviembre de 1927. ADMAE (Paris), N. ${ }^{\circ} 61$.

${ }^{73}$ Esta es la explicación que el embajador italiano en Madrid, Medici del Vascello, afirma haber obtenido de un personaje de la Corte cuyo nombre no revela. Véase: Medici a Mussolini. Madrid, 7 de noviembre de 1927. Tel. N. 8108/446. MAE (Roma), Política, b. 1591.

${ }^{74}$ Peretti a Briand. Madrid, 6 de noviembre de 1927. ADMAE (París), N. ${ }^{\circ} 61$.

${ }^{75}$ Un párrafo significativo de dicho artículo es el siguiente: "La política francesa es cada día más claramente anti-española, particularmente en los nuevos tratados. La actitud anti-española de Francia se manifiesta en el retraso en que ha incurrido para resolver la cuestión de Tánger. Se puede decir que España e Italia están de acuerdo para oponerse a los deseos de hegemonia imperialista de Francia. Estos dos países gozan de la simpatia de Inglaterra por-
} 
Coincidiendo con estos acontecimientos, un hecho nuevo se suma a la larga lista de síntomas de la entente hispano-italiana. Se trata de la creación de un puesto de agregado naval en la Embajada italiana en Madrid y de la designación para cubrírlo de un oficial de Marina de alta graduación, el capitán de navio Gabetti. Peretti hace constar en varios informes a Briand que Italia no tenía agregado naval en Madrid desde la guerra y que Gabetti posee una brillante carrera, siendo consierado en su cuerpo como un oficial de gran valía que, durante su estancia en París en 1922 y 1925 como agregado naval, "dio la impresión de desarrollar una gran actividad y estar notablemente dotado para las funciones que se le confiaron"76. El embajador francés asegura que la designación de Gabetti "muestra la importancia que la Marina Italiana atribuye a ser informada eficazmente sobre el valor del esfuerzo naval español" 77 .

Los acontecimientos aludidos, que se producen encadenadamente en espacio de pocos días, generan nerviosismo en Francia, así como en otros países de Europa como Gran Bretaña, pero también en el interior de España. Peretti se refiere a la emoción reinante en Madrid, en los círculos de sociedad, en las salas de redacción, en los medios políticos y militares, en los que se habla de todo el cúmulo de hechos sintomáticos de la existencia de una entente hispano-italiana. Peretti recoge, por ejemplo, el comentario del general Suárez Inclán, manifestando su preocupación por esta política que califica de descabellada y de auténtica locura en un momento en que existen graves problemas en el Arma de Artillería, con elcuerpo de oficiales en rebelión latente. Por su parte, el duque de Baena, amigo de Alfonso XII y todavía muy bien acogido en palacio, parece que dijo que si Francia había sido muchas veces desleal con España, ésta se disponía a serlo mucho más todavía con Francia. Otro de los comentarios provenía de don Miguel Villanueva, ex-ministro, ex-presidente del Congreso, que "está tanto más emocionado cuanto que relaciona con los acontecimientos actuales la visita de un publicista italiano que hace algunos meses vino a exponerle, así como a varias personalidades políticas más, las razones que podría tener España para acercarse a Italia con vistas a conseguir en Europa una posición que Francia le negaba, y preguntarle cuál sería en su opinión la reacción de España ante esta nueva orientación de su política" ${ }^{78}$. La multitud de comentarios y anécdotas que sobre este asunto relata Peretti a Briand da idea del ambiente existente en el que los rumores

que los intereses británicos se ven irremediablemente comprometidos por los sueños ambiciosos de Francia".

${ }^{76}$ Peretti a Briand. Madrid, 2 de noviembre de 1927, doc. cit.

${ }^{77}$ Roma, 30 de diciembre de 1927: "Creación de una plaza de agregado naval italiano en Madrid". ADMAE (París), N. ${ }^{\circ} 61$.

${ }^{78}$ Peretti a Briand. Madrid, 6 de noviembre de 1927, doc. cit. 
circulan de un lado a otro. La propia respuesta alarmada de El Sol al artículo de El Debate sobre la solidaridad mediterránea es un signo más de que la posibilidad de un acuerdo de carácter anti-francés entre las dos penínsulas es tomada muy en serio y suscita las aprensiones dela opinión liberal del país. El Sol se declara partidario dela política natural de España que debe descansar en la amistad con Francia y Gran Bretaña y, después de felicitarse por las buenas relaciones con Italia, declara: "No querriamos descubrir en ello una finalidad secreta, porque la dipiomacia ha cambiado mucho y no estamos ya en los tiempos en los que los acuerdos internacionales se concertaban entre reyes y Gobiernos sin intervención eficaz de la opinión pública (...). Para establecer una unión íntima en el futuro entre los destinos de España e Italia, habría que olvidar la situación de Italia respecto a otros países, vecinos nuestros y amigos nuestros... Ciertas alianzas equivaldrian a lanzar a nuestro país a una futura conflagración que corre el riesgo de producirse a causa de imperialismos absolutamente extraños al interés español" ${ }^{79}$.

Desde luego en 1927 tanto Italia como España siguen teniendo razones para querer oponerse a Francia. En el caso italiano, es en este año cuando se alcanza la más elevada cota de tensión en las relaciones con París, es el momento de mayor animosidad entre los dos países desde que Mussolini está en el poder: precisamente durante el mes de noviembre. Francia firma un tratado de amistad con Yugoslavia, gran enemiga de Italia por sus intereses en Albania, lo que obtiene la inmediata contestación del Duce, que establece un convenio militar italo-albanés. Por su parte, ya conocemos la frustración de España por la escasa consideración de Francia e Inglaterra hacia lo que cree que son sus derechos como potencia europea y mediterránea. El Gobierno de Primo de Rivera ha dado ya un primer paso en el rechazo del statu quo europeo al abandonar la Sociedad de Naciones. En cuanto a Tánger, España no ha podido obtener nada de Francia en las conversaciones que se están manteniendo en París. Además, otra causa del resentimiento español, aparte de la antipatía "latente e inherente" que el español corriente siente por su vecino del norte (una antipatía que se remonta a varios siglos), lo constituye el sentimiento, mucho más reciente, de que Francia no ha sabido apreciar en lo que vale la contribución del Ejército español a la derrota de Abd el Krim. Los españoles sienten que el mayor peso de la lucha recayó sobre ellos y a esto hizo alusión Primo de Rivera en una conversación con el embajador inglés Rumbold cuando dijo que "después de todo, fuimos nosotros los que desembarcamos en Alhucemas, llevando a cabo de esa forma una operación

${ }^{79} \mathrm{El} \mathrm{Sol}, 2$ de noviembre de 1927. 
particularmente difícil y delicada que allanó el terreno para las operaciones victoriosas futuras" ${ }^{80}$. También entonces el general añadió que todos esos sacrificios de los españoles no se veían compensados por una actitud más flexible de Francia en relación con Tánger, de lo cual se desprendía que la ingratitud francesa era patente.

Sin embargo, Primo de Rivera no va a decidirse nunca por una alianza con Mussolini que comprometa sus relaciones con Francia. ¿Cuáles son los motivos? Hay que destacar, desde luego, la labor desempeñada por Chamberlain que se encarga de dejar claro al dictador que Gran Bretaña no aceptaría una entente de este tipo ni la formación de un "bloque" del que Francia estuviera excluida. Son importantes también sin duda los esfuerzos de Peretti en Madrid y de Quiñones de León en París, que le aconsejarán prudencia y fidelidad a las aliadas tradicionales. Pero quizá la razón más importante sea la desconfianza del marqués de Estella en los planes del Duce, que se demuestra de forma muy clara en el tema de Tánger, como enseguida veremos.

En cuanto a la actitud de Austen Chamberlain, es en la entrevista de Palma, en septiembre de 1927, cuando es más explícito al respecto, pero ya antes de este encuentro estaba claro que Inglaterra, por su política conciliadora y de entendimiento con Francia, no se avendría a una alianza político militar entre España e Italia en el Mediterráneo. El embajador francés en Madrid, empeñado en demostrar que un acuerdo de este tipo es improbable, esgrime como una de las razones fundamentales que justifican su punto de vista el hecho de que estas potencias no cuentan con el imprescindible apoyo inglés: "¿Cómo podría España adquirir compromisos que puedan llevarla a actuar en el mar sin estar segura de que sus barcos no se verán expuestos a los golpes de la flota británica? Sería incomprensible que un acuerdo mediterráneo con Italia fuese firmado por España sin el aliento, o por lo menos, sin la conformidad de Gran Bretaña. Tal es también la impresión de mi colega inglés, con elque he hablado en varias ocasiones sobre la cuestión. Tampoco él cree en esta alianza" ${ }^{81}$. Esta apreciación la repite el embajador en diversas ocasiones para tranquilizar a su Gobierno. Las presiones a las que España se ve sometida por parte italiana "no tienen nada de inquietantes para nosotros - dice Perettimientras Gran Bretaña no las aliente, porque, es inútil disimularlo, el Mare Nostrum que une las costas españolas e italianas está dominado por la flota inglesa" ${ }^{82}$. En la entrevista de Palma, el 30 de septiembre, Chamber-

\footnotetext{
${ }^{80}$ Madrid, Horace Rumbold a Chamberlain. Annual Report, 1927. PRO, FO 371/13439, pág. 5.

${ }^{81}$ Peretti a Briand, 17 de enero de 1927, doc. cit.

${ }^{2}$ Peretti a Briand, 6 de noviembre de 1927, doc. cit.
} 
lain habla explícitamente de la actitud inglesa a este respecto con el dictador español: "Hablé a Primo de Rivera - dice a su embajador en Madridde una forma tan calurosa sobre las relaciones entre los Gobiernos francés y británico, así como sobre la amistad personal existente entre M. Briand, el señor Quiñones de León y yo, que el general difícilmente podrá suponer ahora que yo me prestaria a una política de este género, si alguna vez ha contemplado verdaderamente su realización" ${ }^{83}$. Primo de Rivera sabe que sin el apoyo británico sería imposible embarcarse en un acuerdo dirigido contra su vecino del norte. Pero es que, además teme que una entente con Italia le conduzca a peligrosas aventuras que no interesen por añadidura directamente a España, y, desde luego, no confía en Mussolini, cuya forma de orientar la cuestión de Tánger va a demostrarle que su actitud hacia España no es en absoluto sincera.

\section{LA CUESTION DE TANGER}

$\mathrm{Si}$, en 1926, Primo de Rivera ha accedido a abrir denuevo las negociaciones con Italia con vistas a la firma de un tratado, es porque cree que de esta forma puede presionar a Francia para que abandone su actitud de intransigencia en relación con la demanda española sobre Tánger, al tiempo que gana el apoyo italiano en esta cuestión. A pesar de ciertas noticias publicadas en la prensa extranjera, Primo de Rivera y Mussolini no se han puesto de acuerdo previamente sobre Tánger. El primero envió la nota de la reclamación española a Roma, no en virtud de un acuerdo previo con los italianos, sino porque esperaba contar con el apoyo de Mussolini y este último, que en un principio recibió la nota con sorpresa, enseguida se dio cuenta del partido que podría sacar de esta brusca reapertura de la cuestión tangerina, así que decidió hacer creer a España que contaba con su ayuda. Mussolini va a animar al Gobierno español a defender su reivindicación, no porque por su amistad o afinidad dictatorial con Primo de Rivera desease la incorporación de Tánger a España, sino porque esperaba conseguir importantes ventajas para Italia mediante esta estrategia. Hasta ahora, para Mussolini el tema de Tánger era una cuestión de honor, tras la humillación sufrida por la exclusión de que habia sido objeto en 1923, y su obsesión era que se admitiese la participación italiana en cualquier discusión sobre la administración de la ciudad, en condiciones de igualdad con respecto a las otras tres potencias implicadas, y finalmente conseguirá que Italia sea admitida. Pero ahora no será ya únicamente la admisión

\footnotetext{
${ }^{83}$ Austen Chamberlain a Rumbold, 14 de octubre de 1927. PRO, FO 371/12720.
} 
en las conferencias tangerinas lo que busque sino que, guiado por las sugerencias de su agente diplomático en Tánger, Vanutelli Rey, creía poder utilizar el asunto para obtener beneficios, mucho más interesantes para Italia, no ya en el estrecho marco de Tánger, sino en el ámbito del Marruecos francés. Vanutelli Rey, diplomático "brillante y un poco fantasioso", como lo describe Carocci ${ }^{84}$, pensaba que, apoyando la demanda española y alentando a España a mantenerse firme e intransigente en sus máximas reivindicaciones ${ }^{85}$, se impediría el entendimiento hispanofrancés -ya que, España, animada por Italia, no renunciaría a sus pretensiones y Francia nunca las aceptaría - y, ante el impasse, a consecuencia de lo irreconciliable de las posiciones, Francia se vería finalmente obligada a admitir la convocatoria de una conferencia cuatripartita en la que las cuatro potencias con intereses mediterráneos discutirian el problema de Tánger dentro, ya, del marco general del problema marroquí. En esta conferencia, siempre según Vanutelli Rey, Italia convencería a España de la conveniencia de renunciar a su postura inflexible a cambio de que ambas obtuvieran de Francia, como contrapartida ante esta renuncia, ciertas compensaciones en el Marruecos francés, como el reconocimiento de la nacionalidad italiana y española de todos los residentes en el protectorado francés cuyo origen fuera italiano o español. Mussolini, muy interesado por impedir la desnacionalización de los italianos en las colonias francesas ${ }^{86}$, había anotado siempre al margen de los informes de Vanutelli palabras como "Importante" o "Muy Interesante" ${ }^{87}$. Lo que estaba claro para el Duce era que si, como se pretendía, la cuestión de Tánger era examinada solamente por Francia y España, para someter luego el resultado del acuerdo hispano-francés a Inglaterra e Italia como cosa hecha, se desvanecería por completo la posibilidad de obtener cualquier ventaja en el ámbito marroquí. El jefe fascista ocultará sus cartas, su juego será doble e incluso triple: al mismo tiempo que promete a los españoles su apoyo a la demanda de un Tánger español, asegura a los franceses e ingleses que defiende el punto de vista de la internacionalización, y se guarda para sí

\footnotetext{
${ }^{84}$ Giampiero CarocCl, La Politica estera dell'ttalia fascista, 1925-1928, Bari, 1969.

${ }^{85}$ Es decir, la incorporación de Tánger en la zona española de Marruecos o bien, si esto no era posible, por lo menos ejercer un control efectivo de la zona internacional, lo que implicaba la existencia de un administrador español.

${ }^{86}$ En Túnez, de los 100.000 italianos que viven en esta colonia francesa, alrededor de la mitad han nacido alli pero conservan la nacionalidad italiana en virtud de un convenio de 1896. Francia quiere poner fin a esta situación anómala con una política de desnacionalización que, desde luego, pretende imponer también en su protectorado marroquí, donde Italia no está amparada por ningún convenio semejante al de Túnez, y aquí viven unos 10.000 italianos.

${ }^{87}$ Véase: DDI, vol. IV, núm. 550 y Nota 1 (pág. 429), Vanutelli Rey al secretario general en el Exterior, Chiaramonte Bordonaro. Tánger, 18 de diciembre de 1926. También: DDI, vol. V, N. ${ }^{\circ}$ 30, Vanutelli Rey a Mussolini. Tánger, 23 de febrero de 1927.
} 
sus verdaderas intenciones ${ }^{88}$. Mussolini oculta sus pretensiones a Primo de Rivera hasta que ve que el dictador español está a punto de ceder ante Francia, echando por tierra sus planes. Pero Primo no está dispuesto a entrar en el juego del dirigente italiano, ni a desviar su petición de Tánger hacia la obtención de compensaciones en el Marruecos francés. Mussolini ha tratado de utilizar a Primo de Rivera para conseguir sus objetivos. Primo de Rivera utilizará a su vez a Mussolini para conseguir los suyos propios. Efectivamente, el marqués de Estella hará su propio juego: mantener su reivindicación sobre Tánger y recurrir a la amenaza de un entendimiento con Italia - que en realidad no existe - para tratar de que Francia ceda terreno. En febrero de 1927, el Gobierno español envía al francés un memorándum exponiendo su demanda de incorporación de Tánger como única garantía para evitar que esta ciudad continuara utilizándose como una base rebelde de suministros de armas e intrigas. En el memorándum se insinuaba que si no se concedía esta demanda, España se retiraría de Marruecos, ofreciendo la zona española a los italianos. Esta amenaza, aunque velada, parecía indicar la existencia de un acuerdo de algún tipo entre España e Italia. El embajador francés se daba cuenta sin embargo, de que se trataba de un bluff porque veía con claridad las dificultades con las que tendría que enfrentarse Primo de Rivera ante la enorme pérdida de prestigio que supondría el abandono del protectorado en Marruecos, ya que la opinión pública no podría aguantar que todos los sacrificios de vidas humanas y de dinero hubieran sido en vano. Primo de Rivera sabía, en efiecto, que la insinuación de una retirada española se vería con temor tanto en Francia - que no tenía ningún deseo de emprender la ocupación de la zona española - como por Gran Bretaña - que no quería ver toda la línea de costa frente a Gibraltar en manos de una gran potencia como Francia. En cuanto a una posible cesión a los italianos, Primo también conocía la inquietud que en Francia e Inglaterra originaba el fantasma de una entente hispano-italiana. En varias ocasiones durante las difíciles negociaciones sobre Tánger, el dictador español insinuaria la posibilidad de

\footnotetext{
${ }^{88}$ Mussolini había hecho creer al Gobierno español, en distintas conversaciones mantenidas con el embajador español en Roma, conde de la Viñaza, y en una carta personal a Primo de Rivera, que si España defendia la intervención de Italia en las discusiones sobre Tánger nuevamente abiertas, el Gobierno italiano apoyaría al español en sus tesis frente a las francesas por la amistad que los unia y porque no debia permitirse un aumento de la potencia francesa en el Mediterráneo. Véase: DDI, vol. V, N. ${ }^{\circ} 39$ (Roma, 2 de marzo de 1927); AMAE (Madrid), Correspondencia con Organismos Nacionales: Estado (Correspondencia Particular), Primo de Rivera, legajo 1302 (letra M), Mussolini a Primo de Rivera, Roma, 21 de marzo de 1927. Al mismo tiempo, Grandi, por entonces embajador en Londres, aseguraba a Chamberlain que Roma no apoyaba la petición española (Carte Chamberlain, scatola 53, citado por CAROCCI, op. cit. pág. 365. Véase también carta de Chamberlain a Briand, 6 de septiembre de 1926, en Carte Chamberlain, scatola 50, ibidem.
} 
una nueva orientación de su política exterior, porque "los españoles estaban empezando a valorar los constantes gestos de amistad de Italia". Pero estas amenazas no surten el efecto deseado y finalmente Primo de Rivera se ve obligado a limitar sus demandas. Esta es la mejor prueba de que sólo utiliza el tema de su amistad con Mussolini como una forma de presión, no siendo su intención llevar esta amistad al terreno práctico.

Ante la imposibilidad de poder satisfacer las aspiraciones españolas en Tánger, Primo de Rivera cierra la controversia con Francia, contentándose con pequeñas concesiones como el mando del tabor o jefe de la policía. La postura negociadora es - según declara al embajador italiano"la única lógica y posible" ${ }^{89}$. Por su parte, Mussolini mandará instrucciones para "desistir del estímulo que hemos dado a España para que resistiera, estímulo de cuya efectividad no me hice nunca, por lo demás, excesivas ilusiones, dada la persistente debilidad congénita de la política española frente a la francesa" ${ }^{90}$. El jefe italiano ha tenido tiempo de darse cuenta de que lo más lejos que Primo de Rivera es capaz de llegar con respecto a Italia es al terreno de las buenas intenciones porque la Dictadura española sufre un "incurable afrancesamiento" que le impide aflojar los lazos político-económicos que le unen al país vecino.

Ante el abandono definitivo de que ha sido objeto por parte de España, Mussolini se replanteará la situación y decidirá iniciar una nueva estrategia política consistente en adoptar una actitud favorable al entendimiento con Francia. El Gobierno francés, por su parte, tiene la misma buena disposición para superar las diferencias entre ambos países y una prueba de ello es la presencia en Roma del nuevo embajador francés, Beaumarchais, que asumirá la tarea de "limar las asperezas". En la conferencia tangerina celebrada en París en 1928, Italia tiene un sitio, y logra conseguir la práctica totalidad de sus peticiones en relación con la administración de la ciudad, lo que sirve de plataforma a Mussolini para afirmar que el acuerdo de Tánger debía considerarse como "un feliz preámbulo de la posibilidad de inteligencia italo-francesa".

\footnotetext{
${ }^{89}$ Medici a Mussolini. Madrid, 24 de marzo de 1928. DDI, vol. VI, N. 180.

${ }^{90}$ Mussolini a Medici. Roma, 10 de febrero de 1928. DDI, vol. VI, N. ${ }^{\circ} 94$.
} 


\section{CONCLUSIONES}

La inquietud de los franceses - mayor o menor según los momentos - será a lo largo de toda la Dictadura de Primo de Rivera la de que el dictador pueda dejarse seducir por las propuestas de Mussolini de un entendimiento italo-español que desde el principio se plantea con un claro carácter anti-francés. Hay, de hecho, un anhelo muy sentido en el dictador y en los españoles en general de desempeñar un papel más importante, más activo, en los asuntos internacionales y de que, concretamente, se reconozca a España mayor influencia como potencia mediterránea. Evidentemente, en los momentos en que determinadas circunstancias empujan al dictador a reivindicar esta aspiración con demandas concretas (Tánger y la Sociedad de Naciones) y por tanto le llevan a chocar inevitablemente con las dificultades interpuestas por Francia y Gran Bretaña, es cuando Primo de Rivera se siente más constreñido dentro de la órbita franco-inglesa en que tradicionalmente se ha desenvuelto la política exterior española, y cuando Italia aparece más claramente como posibilidad de servir de contrapeso. Pero la realidad acabará por imponerse y el dictador habrá de reconocer que "todo aconseja y obliga a España", según sus propias palabras, a seguir manteniéndose fiel a su tradicional política dentro de la órbita que marcan Inglaterra y Francia. Los intereses que al fin y al cabo vinculan a España con Francia, la negativa inglesa a apoyar una posible alianza que vaya en contra de su amiga francesa, el recelo hacia las excesivas muestras de agresividad de Mussolini y la creciente desconfianza hacia su actitud "poco clara", todo ello juega sin duda en contra de una hipotética decisión de Primo de Rivera de llegar a un estrecho entendimiento con los italianos. En definitiva, la política del marqués de Estella consiste en tratar de que sus relaciones sean buenas tanto con Italia como con Francia, inclinándose hacia una u otra de las dos potencias según sus intereses de cada momento. Decide colaborar con Francia cuando se presenta la posibilidad de obtener un triunfo decisivo en la guerra de Marruecos, sin dejar por ello de manifestar su simpatía hacia Italia. Sin embargo, cuando lo que pretende es conseguir un cambio en la situación española en Tánger e intentar acabar con la influencia preponderante de Francia sobre esta ciudad, se acerca a Italia, de la que esperi obtener apoyo, pero evitando aun así herir las susceptibilidades de la vecina República. La tan traída y llevada amistad hispano-italiana se quedará en una simple aproximación platónica y aun esto es mucho decir porque hay de hecho una constante duplicidad, un doble juego tanto por parte italiana hacia España como por parte española hacia Italia. Los diplomáticos franceses, y por consiguiente su Gobierno, tienen una interpre- 
tación muy atinada de cómo ocurren las cosas a pesar de no contar siempre con toda la información necesaria. Para ellos está claro que Italia, con sus promesas, intenta que España entre en su juego y ésta, creyendo contar con el apoyo italiano, parece dejarse tentar por las perspectivas que se le abren de un mayor peso en las decisiones de política internacional pero, aunque aparentemente dispuesto a comprometerse, el Gobierno español "escurre el bulto" en el momento de vincularse efectivamente, de pasar del terreno de las declaraciones al de los actos. Hay, así, una utilización de un país por parte del otro para la satisfacción de los intereses propios. Mussolini pretende utilizar a Primo de Rivera para lograr sus ambiciones, mientras que éste utiliza su "flirteo" con Italia, como lo califica el embajador inglés, con la finalidad de que sus tradicionales aliadas, de las que en realidad no piensa separarse, le tengan más en cuenta, pero se repliega siempre que cree que ha ido demasiado lejos, dando entonces largas a Mussolini, con quien en ningún momento llegará a suscribir la alianza anti-francesa que éste pretende. 